\title{
Cartas desde el convento. Modelos epistolares femeninos en la España de la Contrarreforma*
}

\author{
Antonio Castillo Gómez \\ Universidad de Alcalá-Grupo LEA-SIECE \\ antonio.castillo@uah.es
}

Fecha de recepción: 10/11/2012

Fecha de aceptación: 28/05/2013

\begin{abstract}
ReSUMEN
Como es sabido, el convento constituye uno de los espacios privilegiados para la escritura de mujeres en la Edad Moderna, siendo una de sus expresiones más representativas la intensa actividad epistolar que se desarrolló en su interior. Tras valorar distintos elementos de esta producción y la cultura gráfica de las monjas, este ensayo se centra en comparar el epistolario de Teresa de Jesús y la correspondencia de sor María de Jesús de Ágreda con el rey Felipe IV, con el propósito de reflexionar sobre los paradigmas epistolares que se apuntan en ellas. Mientras que las cartas de la religiosa abulense reflejan el valor cotidiano de la comunicación escrita en la reforma de las carmelitas descalzas y la mediación entre estas a través de la escritura; el epistolario de la religiosa concepcionista con el soberano se acerca más al perfil de la "divina madre", es decir, a la autoridad moral desempeñada por aquellas monjas a las que reyes y mandatarios acudieron en busca de consejo espiritual.
\end{abstract}

Palabras clave: Escritura conventual femenina, Escritura epistolar, Teresa de Jesús, sor María de Jesús de Ágreda, Felipe IV, Contrarreforma, Siglo de Oro.

\section{Letters from the convent: female epistolary models in Counter-Reformation Spain}

\begin{abstract}
Convents in the early modern period were, as is widely known, a privileged space for women's writing especially with regard to epistolary activity. Taking into consideration the main features of this written production and the nuns' writing culture, this essay compares the letters of Teresa de Jesús (Teresa of Ávila) to the correspondence of Sister María de Jesús de Ágreda with King Philip IV. This analysis reveals deeply seated epistolary patterns. On the one hand, the Ávila letters show the daily role played by written communication in the Carmelite reform and the importance of writing for the relationships between nuns within the order. On the other hand, Ágreda's correspondence with the king is much closer to the profile of the "divine mother", a profile emphasizing the moral authority played by the nuns, whose spiritual advice was often demanded by kings and other members of the elite.
\end{abstract}

\footnotetext{
* Este trabajo se ha realizado en el marco del Proyecto de Investigación Cultura escrita y memoria popular: tipologías, funciones y políticas de conservación (siglos XVI a XX), financiado por el Ministerio de Economía y Competitividad (Ref. HAR2011-25944). Agradezco las sugerencias y observaciones efectuadas por quienes han evaluado este texto antes de su publicación.
} 
Key words: Female writing in convents, epistolary writing, Teresa de Jesús, María de Jesús de Ágreda, Philip IV, Counter-Reformation, Golden Age.

\section{PAPEL, PLUMA Y TINTA}

En palabras del jurista Juan de Arce de Otálora, escritas en la segunda mitad del Quinientos, las monjas sustentaban toda su vida "con una mano de papel y tres plumas y una

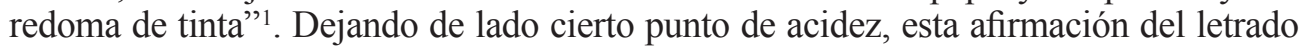
vallisoletano daba fe de una realidad indiscutible. Mientras que en otros ámbitos de la vida de las mujeres, el conocimiento de la escritura pudo ser menos necesario e incluso estar más afectado por el género y la condición social; en el interior de los conventos las monjas dispusieron de mayores oportunidades para aprender, de tiempos para escribir, motivaciones para hacerlo y de un lugar para ello, la celda ${ }^{2}$, cuál habitación propia avant la lettre. De hecho, la reglamentación de las tareas asignadas a los diferentes oficios conventuales apunta a comunidades donde el alfabetismo estaba más extendido que en otros espacios femeninos. Si nos detenemos en las Constituciones que Teresa de Jesús estableció para los monasterios de carmelitas descalzas, leemos en ellas que se encomendaba a la priora el gobierno material y espiritual, para lo que indudablemente precisaba de una buena competencia escrita. De las clavarias se dice expresamente que debían saber escribir y contar para poder revisar las cuentas que cada mes les presentaba la receptora, ocupada a su vez en "escribir gasto y recibo"

En el orden de la lectura, la priora debía procurar que en el convento hubiera "buenos libros, en especial Cartujanos, Flos Sanctorum, Contemptus mundi, Oratorio de Religiosos, los de Fr. Luis de Granada, y del Padre Pedro de Alcántara, porque es en parte tan necesario este mantenimiento para el alma, como el comer para el cuerpo". Por esto mismo, en el oficio de maitines una monja, designada por la madre superiora, tenía que leer "un poco en romance del misterio en que se ha de pensar otro día". Y a su vez, la maestra de novicias tenía el cometido de leerles las Constituciones y de enseñarles "todo lo que han de hacer", incluso a leer:

Mire la que tiene este oficio que no se descuide en nada, porque es criar almas para que more el Señor. Trátelas con piedad y amor, no se maravillando de sus culpas, porque han de ir poco a poco, y mortificando a cada una según lo que viere puede sufrir su espíritu. Haga más caso de que no haya falta en las virtudes, que en el rigor de la penitencia. Mande la priora la ayuden a enseñarlas a leer ${ }^{4}$.

\footnotetext{
1 Arce de OtÁlora, J. de: Coloquios de Palatino y Pinciano, edición de J. L. Ocasar, Madrid, Biblioteca Castro, 1995, vol. II, p. 859.

2 Weaver, E. B.: "Le muse in convento. La scrittura profana delle monache italiane (1450-1650)", en Scaraffia, L. y Zarri, G. (eds.): Donne e fede. Santità e vita religiosa in Italia, Roma-Bari, Laterza, 1994, pp. 255-256.

3 Teresa de Jesús: Las constituciones, en ID.: Obras completas, dirección de Alberto Barrientos, Madrid, Editorial Espiritualidad, $1984^{3}$, pp. 1146-1147 y 1136, respectivamente.

4 Ibidem, pp. 1136, 1135 y 1148, para esta y las anteriores citas. Sobre la práctica lectora en las comunidades religiosas observantes, remito a mi trabajo "Leer en comunidad. Libro y espiritualidad en la España del Barroco", Via Spiritus, 7 (2000), pp. 114-119.
} 
Desde otro punto de vista, los datos sobre el alfabetismo femenino inciden en la misma dirección. Tomando como botón de muestra el caso de Granada, ciudad para la que se dispone de valores susceptibles de cotejo, se constata lo siguiente: por un lado, una capacidad de suscripción autógrafa de los documentos notariales que implicó al $19 \%$ de las mujeres durante el período 1605 a $1609^{5}$; y por otro, una competencia de escritura del $78 \%$ en las monjas que profesaron en el convento de San José entre 1584 y 1636 , y del $66 \%$ con posterioridad a $1649^{6}$. Por más que dichos porcentajes deban tomarse con la cautela que exige una documentación, de distinta procedencia, que no siempre es totalmente representativa ni tampoco estaba pensada para un tratamiento estadístico, esto no es óbice para que les podamos asignar un cierto valor indiciario.

Unas y otras fuentes coinciden en señalar al convento como un lugar privilegiado para la adquisición y expresión escritas ${ }^{7}$, sin que por ello la escritura dejara de ser, también allí, un instrumento de poder y diferencia ${ }^{8}$. En el interior de los claustros fueron bastantes las mujeres que adquirieron cierta familiaridad con la cultura escrita, ya fueran enseñadas por las maestras de novicias, ya por otras monjas más veteranas o bien aprendieran de manera autodidacta. Ana de San Bartolomé, por ejemplo, lo hizo imitando la letra de Teresa de Jesús, según veremos más adelante; en tanto que María de Jesús, la Sabia de Coria, hija de labradores al servicio del duque de Alba, atribuyó su aprendizaje a la inspiración divina al tiempo que insistió en la dificultad de la tarea. Según era norma común en tantas autobiografías espirituales ${ }^{9}$, en el caso de esta monja también fue el confesor quién le mandó escribir, advirtiéndole que no se preocupara si "no sabía escrivir ni avía tomado en su vida pluma en su mano",

5 VINCENT, B.: "Lisants et non-lisants des royaumes de Grenade et de Valence à la fin du XVI siècle", en De l'alphabétisation aux circuits du livre en Espagne, XVI ${ }^{e}$-XIXe siècles, París, CNRS, 1987, p. 97. Comparado con los valores obtenidos para otras ciudades, en todos los casos estaríamos hablando de una alfabetización femenina que rara vez pasó de ese umbral. Así, para Ávila se ha estimado que el 12,5\% de las mujeres pudieron estar alfabetizadas entre 1580 y 1610 , muy similar al 11\% propuesto para el interior de Andalucía de 1595 a 1632, superior al 6,8\% barajado para la región de Toledo en la primera mitad del siglo XVII e inferior al 28\% señalado para la diócesis de Cuenca en idéntico intervalo. Véase al respecto ViÑao FraGo, A.: "Alfabetización y primeras letras (siglos XVI-XVII)", en CAstillo Gómez, A. (comp.): Escribir y leer en el siglo de Cervantes, Barcelona, Gedisa, 1999, pp. 74-75.

6 Obra Sierra, J. M. de la; Osorio Pérez, M. J.; y Moreno Trujlllo, M. A.: "Mujer y cultura escrita. A propósito del libro de profesiones del convento de San José de Granada (1584-1684)", Estudis Castellonencs, 6/2 (1994-1995), pp. 965-977.

7 Ferrús Antón, B.: Discursos cautivos: convento, vida, escritura, Valencia, Universitat de València, 2004.

8 Aunque referido a fechas algo más avanzadas así lo indica el distinto grado de alfabetismo de las monjas de coro y de las freilas en el monasterio cisterciense de San Bernardo en Alcalá de Henares. Véase GonZÁLEZ DE LA PEÑA, M. V.: Mujer y cultura gráfica. Las Reverendas Madres Bernardas de Alcalá de Henares (siglos XVIII-XIX), Alcalá, Institución de Estudios Complutenses, 2001, pp. 55-78.

9 Poutrin, I.: Le voile et la plume. Autobiographie et sainteté féminine dans l'Espagne moderne, Madrid, Casa de Velázquez, 1995, pp. 143-148; Herpoel, S.: A la zaga de Santa Teresa: autobiografias por mandato, Ámsterdam, Rodopi, 1999, pp. 83-91 y 144-154; AmElang, J. S.: “Autobiografías femeninas", en Morant, I. (dir.): Historia de las mujeres en España y América Latina, vol. II: OrTEGA, M.; Lavrín, A.; y Pérez Cantó, P. (coords.): El mundo moderno, Madrid, Cátedra, 2005, pp. 155-168; Castillo Gómez, A.: "Dios, el confesor y la monja. La autobiografía espiritual femenina en la España de los siglos XVI y XVII", Syntagma. Revista del Instituto de Historia del Libro y de la Lectura, 2 (2008), pp. 59-76; y ÁlVAREZ Santaló, L. C.: Así en la letra como en el cielo. Libro e imaginario religioso en la España moderna, Madrid, Abada, 2012, pp. 309-325. 
puesto que el mismo Dios que le había "movido el entendimiento para oír lo que se refiere, le moverá los dedos para que lo traslade al papel". Obedeció, "aplicando la pluma adonde avía de escrivir", y de este modo "empeçó, sin saber, a hazer una forma clara, con división de las palabras y de los caracteres, que se dexa leer facilísimamente sin fatiga" 10 .

La iniciación autodidacta, guiada aparentemente por manos divinas, fue asimismo el procedimiento empleado por María de Cristo, dado que su padre no quiso que aprendiera porque "decía que las mujeres no habían menester saber escribir". Empujada a hacerlo, refiere que el Señor acudió en su ayuda, de tal modo que un día cogió la pluma en la mano y empezó a escribir "como si hubiera muchos tiempos que lo ejercitara según la velocidad con que lo hice"11.

La actitud del padre de María de Cristo coincidía con el espíritu restrictivo de la Contrarreforma, época en la que se sitúa buena parte de la producción escrita de las religiosas españolas. La puerta entreabierta en el primer cuarto del siglo XVI por gentes como Luis Vives - para quien las mujeres podían aprender a leer siempre que lo hicieran "en buenos libros de virtud" y a escribir usando como muestra "alguna cosa sacada de la sagrada escritura o alguna sentencia de castidad tomada de los preceptos de filosofia"12 - dejaba de estarlo en el discurso de algunos moralistas barrocos a causa del celo integrista surgido del Concilio de Trento. Uno de los más severos fue el jesuita Gaspar de Astete, en cuyo Tratado del gobierno de la familia y estado de las viudas y doncellas (1597), más permisivo con la lectura femenina si tenía lugar entre las paredes de la casa y guiada por el padre, la madre, un hermano o una mujer anciana, sostuvo que a las mujeres no les era absolutamente necesario aprender a escribir y contar puesto que su "gloria" estaba en el huso, la rueca y la almohadilla, pero nunca en la pluma o en la espada, atributos del varón:

De más desto, la muger no ha de ganar de comer por el escreuir ni contar, ni se ha de valer por la pluma como el hombre. Antes assí como es gloria para el hombre la pluma en la mano, y la espada en la cinta, assí es gloria para la muger el huso en la mano y la rueca en la cinta y el ojo en la almohadilla ${ }^{13}$.

En términos generales, la lectura concitó juicios más favorables siempre que se ciñese a textos sagrados y devotos ${ }^{14}$; en tanto que la escritura fue objeto de mayor rechazo, ya que una vez adquirida lo mismo podía usarse para narrar una experiencia religiosa

10 Arcos, F. DE: La Sabia de Coria. Vida de la venerable María de Jesús, natural de Guijo, Madrid, Francisco Nieto, 1671, p. 21.

11 Vida de la Venerable María de Christo, 1671-1678 (manuscrito autógrafo), Biblioteca Nacional de España (BNE), Ms. 3647, fol. 2v.

12 VIVES, J. L.: Instrucción de la mujer cristiana (1524), Madrid, Fundación Universitaria Española-Universidad Pontificia de Salamanca, 1995, p. 56. Insisto en matizar que su defensa de la lectura femenina se circunscribía estrictamente a dichas obras: "si no lee de buena gana buenos libros, le deben totalmente quitar que no lea, y si ser puede que se desbecerre de leer, porque es muy mejor carecer de la cosa buena que usar mal de ella". Ibidem, p. 65.

13 Astete, G. DE: Tratado del govierno de la familia, y estado de las viudas y donzellas, Burgos, Juan Bautista Varesio, 1603 (1597, en el colofón), pp. 170-171.

14 Fernandes, M. De L. Correia: Espelhos, cartas e guias. Casamento e espiritualidade na Península Ibérica, 1450-1700, Oporto, Instituto de Cultura Portuguesa, 1995, pp. 191-197 y 393-402; y GAGLIARDI, D.: 
que para algo tan sospechoso como escribir cartas o billetes de amor ${ }^{15}$. En su diatriba contra la alfabetización de las mujeres, el padre Astete aludió precisamente a esta circunstancia, confirmando de paso la extensión que la práctica epistolar había alcanzando entre ellas: "muchas mugeres andan y perserveran en malos tratos porque se ayudan del escrevir para responder a las cartas que reciben, y como escriven por su mano encubren mejor los tratos que traen y hazen más seguramente lo que quieren" 16 . Similar temor lo puso de relieve el franciscano Juan de la Cerda en su obra Vida política de todos los estados de mujeres (1599) ${ }^{17}$, mientras que, contemporáneamente, Fr. Marco Antonio de Camos, en Microcosmia y gobierno universal del hombre cristiano (1592), se mostró más proclive a que las mujeres aprendieran a escribir puesto que así podrían llevar la contabilidad y el gobierno de la casa ${ }^{18}$, es decir, justo lo contrario de lo que Gaspar de Astete pretendió cinco años después.

Pero cuando se habla de la actividad escrita de las monjas no debe olvidarse que la vida conventual estuvo sujeta a cierta vigilancia, diariamente a cargo de la priora y de modo regular por los padres superiores de cada orden religiosa. Dadas estas circunstancias, tal vez convenga matizar la tesis que presenta el convento como el lugar donde tuvo efecto la contienda fundacional de la escritura del sujeto femenino, siendo la razón aducida que en las celdas las monjas tuvieron mayores posibilidades "para hablar para sí mismas y de Dios" $"$. Ni todas disfrutaron de idénticas opciones ni los monasterios fueron comunidades abiertamente igualitarias. Como expuso María José de la Pascua, apoyándose en los escritos de María de San José, el espacio religioso fue a menudo un "campo de batalla" en el que las monjas sólo pudieron "imponer sus vivencias y opiniones con dificultad" 20 . Cierto es que, al profesar, eludieron las obligaciones del matrimonio y de la vida familiar disponiendo de un tiempo propio que tal vez no hubieran tenido en la vida civil; pero, por otro lado, debieron responder a los mandatos de los confesores, quienes estuvieron detrás de muchas de sus actividades de escritura, todavía más tras el Concilio de Trento. Si antes había predominado una cierta veneración hacia ellas por parte de los religiosos, en particular a las "divinas madres" por su

Urdiendo ficciones. Beatriz Bernal, autora de caballerías en la España del siglo XVI, Zaragoza, Prensas Universitarias de Zaragoza, 2010, pp. 56-66.

15 Álvarez Santaló, L. C.: “Algunos usos del libro y la escritura en el ámbito conventual: el Desengaño de Religiosos de Sor María de la Antigua (1614-1617)", en GonzÁlez SÁnchez, C. A. y Vila Vilar, E. (comp.): Grafias del imaginario. Representaciones culturales en España y América (siglos XVI-XVIII), México, D.F., Fondo de Cultura Económica, 2003, pp. 178-179.

16 Astete, op. cit. (nota 13), p. 171.

17 “el escrevir ni necesario ni lo querría ver en las mujeres, no porque ello de suyo sea malo, sino porque tienen la ocasión en las manos de escrevir billetes y responder a los que hombres livianos les embían. Muchas ay que saben este exercicio y usan bien del, más usan otras del tan mal que no sería de parecer que lo aprendiessen todas", CERDA, J. DE LA: Vida política de todos los estados de mujeres, Alcalá de Henares, Juan Gracián, 1599, fols. 12v-13r.

18 Baranda Leturio, N.: Cortejo a lo prohibido. Lectoras y escritoras en la España moderna, Madrid, Arco/Libros, 2005, p. 69.

19 Cirlot, V. y Garí, B.: La mirada interior. Escritoras místicas y visionarias en la Edad Media, Barcelona, Martinez Roca, 1999, p. 11.

20 Pascua SÁnchez, M. J. DE la: "Escritura y experiencia femenina: la Memoria de las Descalzas en el Libro de Recreaciones de sor María de San José”, Trocadero. Revista de Historia Moderna y Contemporánea, 12-13 (2000-2001), p. 298. 
ejemplaridad espiritual ${ }^{21}$; después, se instauró un modelo de relación sensiblemente más rígido, coercitivo y basado en la obediencia al confesor ${ }^{22}$.

\section{LA DIFUSIÓN DE LA ESCRITURA EPISTOLAR EN LOS CONVENTOS FEMENINOS}

Pertrechadas de papel, pluma y tinta, bastantes monjas del Siglo de Oro se prodigaron escribiendo. Sin restar un ápice de entidad a la creación literaria, poética y teatral desplegada en el interior de los conventos barrocos, a uno y otro lado del Atlántico ${ }^{23}$, la actividad escritora de las monjas tuvo otra cara más cotidiana e instrumental que se plasmó, principalmente, en la amplia producción autobiográfica y epistolar. Su cronología corre en paralelo al desarrollo de la Contrarreforma pero también debe ligarse al crecimiento de la alfabetización durante la temprana Edad Moderna y, en lo tocante a las cartas, a la notable extensión de la correspondencia ${ }^{24}$.

En cuanto a las autobiografías espirituales está más que estudiado que su práctica se desencadenó a raíz de la circulación manuscrita del Libro de la Vida de Teresa de Jesús y aún más tras la edición impresa de 1588, realizada por voluntad de Fr. Luis de León ${ }^{25}$. Respecto de las cartas, haría falta disponer de un inventario con objeto de afinar la periodización si bien los testimonios más conocidos apuntan en la misma dirección. Su mayor abundancia desde entonces debe parte del éxito a la religiosidad emotiva y fuertemente agitada de la Contrarreforma, que tuvo en el escrito un espacio predilecto de expresión. Epistolarios como los de Teresa de Jesús ${ }^{26}$, Ana de San Bartolomé ${ }^{27}$, Isabel

21 Prosperi, A.: “Dalle 'divini madri' ai 'padri spirituali"”, en Schulte von Kessel, E. (ed.): Women and Men in Spiritual Culture, La Haya, Staatsuitgeverij, 1986, pp. 71-91; y ZARri, G.: Le sante vive. Profezie di corte e devozione femminile tra '400 e '500, Turín, Rosenberg \& Sellier, 1990.

22 SÁnchez Ortega, M.-H.: Confesión y trayectoria femenina. Vida de la Venerable Quintana, Madrid, CSIC, 1996, pp. 271-276; y Bilinkoff, J.: Related Lives. Confessors and their Female Penitents, 1450-1750, Ithaca-Nueva York, Cornell University Press, 2005, pp. 32-45.

23 Zavala, I. M. (ed.): Breve historia de la literatura feminista, vol. 4, La literatura escrita por mujer: desde la Edad Media hasta el siglo XVIII, Barcelona, Anthropos, 1997; Bosse, M., Potthast, B., y Stoll, A. (eds.): La creatividad femenina en el mundo barroco hispánico. María de Zayas - Isabel Rebeca Correa - Sor Juana Inés de la Cruz, Kassel, Reichenberger, 2000, 2 tomos; Lavrín, A. y Loreto, R. (eds.): Monjas y beatas. La escritura femenina en la espiritualidad barroca novohispana (siglos XVII y XVIII), Puebla, Universidad de las Américas; México, D. F., Archivo General de la Nación, 2002; CABAllé, A. (dir.): La vida escrita por las mujeres. Obras y autoras de la literatura hispánica e hispanoamericana, vol. I: Por mi alma os digo. De la Edad Media a la Ilustración, Barcelona, Círculo de Lectores, 2003; BARANDA Leturio, N. y Marín PinA, M. C. (eds.): Letras en la celda. Cultura escrita de los conventos femeninos en la España moderna, MadridFrankfurt, Iberoamericana-Vervuert, 2014.

24 Castillo Gómez, A: Entre la pluma y la pared. Una historia social de la escritura en los Siglos de Oro, Madrid, Akal, 2006, pp. 19-57.

25 Herpoel, op. cit. (nota 9), pp. 32-39.

26 Me remito a las dos ediciones con las que he trabajado: TeresA DE Jesús, Obras completas, op. cit. (nota 3); e ID: Cartas, edición de Tomás Álvarez, Burgos, Monte Carmelo, 1997.

27 Ana de San Bartolomé: Obras completas, edición de Julián Ariza, Burgos, Monte Carmelo, 1999. 
de los Ángeles ${ }^{28}$, Ana de Jesús ${ }^{29}$, Leonor de San Bernardo ${ }^{30}$, Beatriz de la Concepción ${ }^{31}$, María de Jesús de Ágreda ${ }^{32}$ o Benedicta Teresa ${ }^{33}$, entre otros, corresponden justamente a religiosas que vivieron y escribieron entre las décadas finales del Quinientos y la primera mitad del Seiscientos.

Si nos fijamos en las monjas citadas, salvo Benedicta Teresa, benedictina, y María de Ágreda, concepcionista franciscana, las demás son carmelitas, lo que abunda en la importancia dada a la comunicación epistolar en dicha congregación siguiendo el modelo establecido por la fundadora. Esta circunstancia la pudo comprobar in situ, un siglo después, Fr. Manuel de Santa María en la misión que llevó a cabo, entre el 18 de junio de 1761, cuando visitó el convento de Duruelo (Ávila), y el 21 de julio de 1764, fecha de su llegada a las Carmelitas Descalzas de Segovia, comisionado por Fr. Pablo de la Concepción, general de los carmelitas, para que buscara y sacara copia autentificada de los escritos de Teresa de Jesús. Durante estos años recorrió la geografía carmelitana indagando "entre infinidad de papeles y monumentos de librerías y archivos" para escribir su crónica. Aunque su objetivo principal eran los autógrafos de Teresa de Jesús y Juan de la Cruz ${ }^{34}$, también aprovechó el viaje para sacar traslado de otras cartas que fue encontrando en los distintos monasterios, hasta un total de 70 ejemplares, todas ellas debidamente certificadas por él y por el padre o abadesa del respectivo convento ${ }^{35}$. He aquí su explicación de la empresa:

28 Cartas de la Madre Isabel de los Ángeles, O. C. D. (1565-1644), edición de Pierre Sérouet, Burgos, Monte Carmelo, 1963.

29 Torres, C.: Ana de Jesús, cartas (1590-1621): religiosidad y vida cotidiana en la clausura femenina del Siglo de Oro, Salamanca, Ediciones Universidad de Salamanca, 1995.

30 Leonor de San Bernardo: Lettres (1634-1638), edición de Pierre Sérouet, París, Desclée De Brouwer, 1981.

31 Lettres choisies de Béatrix de la Conception, edición de Pierre Sérouet, París, Desclée de Brouwer, 1967.

32 Sobre María de Ágreda como escritora de cartas, véase la reciente aportación de MorTE Acín, A.: Misticismo y conspiración. Sor María de Ágreda en el reinado de Felipe IV, Zaragoza, Institución "Fernando el Católico", 2010, pp. 245-283.

33 Archivo Histórico Nacional (AHN), Inquisición, leg. 3692 ${ }^{1}$, fols. 478-731. Una parte mínima de las cartas dirigidas al conde-duque de Olivares y a Fr. Francisco García Calderón fue publicada por BARBEITO, I.: Cárceles y mujeres en el siglo XVII. Razón y forma de la Galera. Proceso inquisitorial de San Plácido, Madrid, Editorial Castalia; Instituto de la Mujer, 1991, pp. 127-163. Véase también BoyLE, M.: "Inquisition and epistolary negotiation: examining the correspondance of Teresa de la Valle y Cerda", Letras femeninas, 35/1 (2009), pp. 293-310; y GonZÁlez de la PeÑA, M. V.: “"No sé dejar la pluma': las cartas de Benedicta Teresa al conde- duque de Olivares", en Castillo Gómez, A. y Sierra Blas. V. (dirs.): Cartas - Lettres - Lettere. Discursos, prácticas y representaciones epistolares (siglos XIV-XX), Alcalá de Henares, Universidad de Alcalá, 2014 , pp. 307-328.

34 Obras de San Juan de la Cruz y de Santa Teresa de Jesús, copiadas por Fr. Manuel de Santa María, Fr. Andrés de la Encarnación y Fr. Tomás de Aquino y autentificadas ante notarios apostólicos, BNE, Ms. 13245.

35 SAnta María, M. DE: Espicilegio historial o Colección de diferentes especies sueltas y misceláneas tocantes a la Historia de la Reforma, etc. En esta N. Primitiva Provincia de Castilla la Vieja, BNE, Ms. 8713. Las cartas corresponden a Ana de San Bartolomé, Ana de San Agustín, Catalina de Cristo, Catalina de Jesús, María Ana Francisca de los Ángeles, Gabriela de San José, Isabel de los Ángeles, Beatriz de Jesús y Ana de Jesús. A fin de mostrar el rigor de su trabajo empleó la tinta negra para el texto copiado y la roja para señalar las letras suplidas en la lectura y para otras anotaciones. 
Muy tarde me ha ocurrido al pensamiento esta utilíssima diligencia, siendo al parecer un pensamiento tan obvio a quien ha andado quatro años entre infinidad de papeles y monumentos de librerías y archivos. Pero la verdad es que, arrebatado y embebido enteramente en el assumpto principal de mi comissión, que son los pertenecientes a escritos originales de Nuestros Gloriosos Padres Santa Teresa de Jesús y San Juan de la Cruz, y apuntaciones chronológicas e historiales sobre diferentes cartas de la Santa (materia sobradíssima para otro tanto más tiempo), apenas le he tenido para recoger de passo algunas otras no inútiles especies, remitidas ya o en estado de remitirse a los archivos de la Orden, contentándome por lo respectivo a otras sueltas y mysceláneas, ahunque no menos oportunas, útiles y convenientes, con irlas participando a Madrid en cartas particulares ${ }^{36}$.

Es indudable, en suma, la amplia difusión de la escritura epistolar en los monasterios femeninos y masculinos, aunque estos no sean ahora objeto de nuestro interés. Su estudio, sin embargo, debe afrontar la dificultad que entraña el acceso a dichos espacios, especialmente a los conventos de clausura, así como la frecuente dispersión de dichos fondos por la geografía monástica de cada orden y en otros acervos, en buena parte debido a la veneración hacia sus autoras ${ }^{37}$, sumada a las pérdidas acontecidas por muy variados motivos. Compárese, por ejemplo, la dispar localización de las cartas de Teresa de Jesús o de Ana de San Bartolomé, con el mayor agrupamiento de la correspondencia de María de Ágreda con Felipe IV, por un lado ${ }^{38}$, y con don Fernando y don Francisco de Borja o la duquesa de Alburquerque, por otro ${ }^{39}$. Obviamente las razones son diferentes: mientras que en este caso se trata de epistolarios concretos, la correspondencia de las monjas carmelitas presenta una amplia variedad de destinatarios y, por tanto, de lugares de conservación. Nótese que las cerca de 470 cartas de Teresa de Jesús y las 664 de Ana de San Bartolomé se hallan repartidas por los diferentes conventos de la Orden, en bibliotecas y archivos públicos o en colección particulares, hasta en 65 ciudades distintas si hablamos de Ana de San Bartolomé ${ }^{40}$. A todo esto debe añadirse que el volumen de las cartas conservadas suele ser una parte mínima de las que pudieron escribirse conforme delatan las continuas referencias a misivas previas no respondidas o que ni siquiera llegaron a su destino.

\footnotetext{
36 Ibidem, fol. $1 \mathrm{r}$.

37 Scattigno, A.: "Lettere dal convento", en ZARri, G. (ed.): Per lettera. La scrittura epistolare femminile tra archivio e tipografia (XV-XVII secolo), Roma, Viella, 1999, p. 321.

38 De las varias ediciones que existen de este epistolario cito únicamente las que he consultado: Cartas de la Venerable Madre Sor María de Ágreda y del señor rey don Felipe IV, precedidas de un bosquejo histórico por D. Francisco Silvela, Madrid, Sucesores de Rivadeneyra, 1885, 2 tomos; Cartas de sor María de Jesús de Ágreda y de Felipe IV, edición de Carlos Seco Serrano, en Epistolario español, IV-V, Madrid, Atlas, 1958 (BAE, 108-109); y María de Jesús de ÁGreda: Correspondencia con Felipe IV. Religión y Razón de Estado, introducción de Consolación Baranda Leturio, Madrid, Castalia-Instituto de la Mujer, 1991.

39 Baranda Leturio, C.: "Las cartas de Sor María Jesús de Ágreda a don Fernando y a don Francisco de Borja: los manuscritos de las Descalzas Reales", en Zugasti, M. (ed.): Sor María de Jesús de Ágreda y la literatura conventual femenina en el Siglo de Oro, Soria, Universidad Internacional Alfonso VIII-Diputación Provincial de Soria, 2008, pp. 13-32; e ID.: Cartas de Sor María de Jesús de Ágreda a Fernando de Borja y Francisco de Borja (1628-1684). Estudio y edición, Valladolid, Ediciones Universidad de Valladolid, 2013. Respecto al intercambio epistolar con la duquesa de Alburquerque, véase Chicharro Crespo, E.: "La correspondencia familiar en el ámbito conventual femenino: cartas de María de Jesús de Ágreda a la duquesa de Alburquerque", Via spiritus, 20 (2013), pp. 191-213.

40 Ana de San Bartolomé, op. cit. (nota 27), p. 792.
} 


\section{USOS EPISTOLARES DE LAS MONJAS ÁUREAS}

Asumiendo la parte de tópico y de legitimación de la subversión inherente a determinados actos de escritura, máxime si son protagonizados por mujeres, es innegable que tras una porción significativa de la producción escrita de las monjas estaba la figura del confesor y el control de los superiores de cada Orden. Se ha advertido expresamente en las autobiografías espirituales, el género más específicamente femenino junto a la poesía mística, pero igualmente puede señalarse de la correspondencia. Harto expresivo es el testimonio de Filipa de Jesús, hija del Prior do Crato, rival de Felipe II en su conquista del trono portugués, a quien en su destierro castellano por distintos conventos se le prohibió que escribiera cartas, por más que esto no le impidiera hacerlo a veces a hurtadillas, aunque luego le fueran requisadas por sus guardianes ${ }^{41}$. En consonancia con las reglas monásticas que durante la Contrarreforma prescribieron la existencia de una estancia conventual para la escritura a fin de que esta se hallara más vigilada, a la vez que encomendaron a la abadesa que tuviera el cargo de que la lectura se realizara en la biblioteca y no en las celdas ${ }^{42}$, las Constituciones de las Carmelitas Descalzas comisionaron a la priora para que permaneciera atenta a la comunicación de las monjas con el exterior, además de fijar la sanción que podía recaer sobre ellas:

Y si alguna cosa fuere osada a recibir o dar algunas cartas y leerlas sin licencia de la madre priora, o cualquiera cosa enviare fuera, o lo que le han dado retuviera para sí; aquélla [hermana] asimismo, por los excesos de la cual hermana fuere alguno en el siglo [escandalizado], aliende de las penas dichas por las constituciones, a las horas canónicas y a las gracias después de comer estará postrada ante la puerta de la iglesia a las hermanas que pasen ${ }^{43}$.

Lejos de ser enteramente libres, los intercambios epistolares estaban afectados por distintas expresiones de lo que Octavio Paz, al estudiar la obra de sor Juan Inés de la Cruz, llamó el "código de lo decible" ${ }^{44}$. Al igual que otros escritos de monjas ${ }^{45}$, las cartas eran el fruto de la negociación establecida entre la libertad de escribir, los temores a hacerlo cuando quien escribe es una mujer, la autocensura respecto de ciertos asuntos, las restricciones impuestas por determinados corresponsales y, por supuesto, la vigilancia ejercida por los superiores ${ }^{46}$. Después de todo, como le dijo sor María a Felipe IV en una de sus misivas, "por cartas no se puede decir lo que se desea, ni exponerlo a

41 Bouza, F.: "Memorias de la lectura y escritura de las mujeres en el Siglo de Oro", en Morant, I. (dir.), op. cit. (nota 9), t. II, p. 180.

42 CABIBbo, S.: "Scrivere in monastero nel XVII secolo", en ModicA, M. (ed.): Esperienza religiosa e scritture femminili tra Medioevo ed età moderna, Acireale, Bonanno Editore, 1992, pp. 84-85.

43 Teresa de Jesús, op. cit. (nota 3), p. 1154, nº 54.

44 Paz, O.: Sor Juana Inés de la Cruz o las Trampas de la Fe, México, D.F., FCE, 1982.

45 Bilinkoff, op. cit. (nota 22), pp. 46-75.

46 A esto se han referido también LAVRIN, A.: "La celda y el siglo: epístolas conventuales", en MorAÑA, M. (ed.): Mujer y cultura en la Colonia hispanoamericana, Pittsburgh, Instituto Internacional de Literatura Iberoamericana, 1996, p. 144; y COHEN IMACH, V.: "Escribir desde el claustro. Cartas personales de monjas", Telar. Revista digital del Instituto Interdisciplinario de Estudios Latinoamericanos, 1 (2004), p. 2, http://www. filo.unt.edu.ar/centinti/iiela/revista_telar/index.htm (acceso: 6-10-2013). 
la debilidad de un papel" ${ }^{\prime 7}$. En el epistolario de Teresa de Jesús se encuentran también distintas muestras de las precauciones que tomó en su correspondencia, en particular debido a las dificultades que los superiores del Carmelo pusieron a su reforma. Así, en una misiva a Francisco Salcedo, escrita en Salamanca a 3 de agosto de 1573, dio cuenta del desasosiego e inconvenientes que podrían acarrearle, de conocerse, algunos "negocios" en los que entonces andaba metida, seguramente la fundación de un colegio de doncellas en Medina del Campo:

Diga a nuestro padre provincial [Ángel de Salazar] que, unas que envío ahí para Medina, que suplico a su merced no las lleve sino persona muy cierta, porque es sobre los negocios que dije el otro día a su merced, y podría venirnos gran desasosiego y hartos inconvenientes para el servicio de Dios ${ }^{48}$.

Descendiendo a la materialidad de las cartas de religiosas en la España barroca, primeramente debemos señalar el uso habitual del pliego de papel, que fue el formato más extendido en la época sin que fuera impedimento para que también se empleara el cuarto de pliego ${ }^{49}$. En lo que concierne a la disposición de la escritura, era más común que se respetara el espacio blanco entre la invocación y el comienzo de la carta que en el margen izquierdo, muchas veces invadido por la escritura ${ }^{50}$. Unas vez plegadas se anotaba el sobrescrito, es decir, el nombre y razón del destinatario, así como las tasas $\mathrm{y}$, eventualmente, la persona encargada del transporte y otros datos, siendo lacradas con el correspondiente sello. En el caso de Teresa de Jesús, reproducía el monograma del nombre de Jesucristo (IHS) ${ }^{51}$, incorporado asimismo como invocación en la parte superior de sus cartas con el añadido de una cruz encima de la letra $\mathrm{H}$.

El texto sigue el esquema básico en cinco partes: invocación, saludo, texto, despedida de respeto y suscripción autógrafa ${ }^{52}$. En esto no se aprecia ninguna particularidad en las cartas de monjas a excepción de la fuerte impronta religiosa que se percibe tanto en el estilo como en la invocación, por lo común en forma de cruz y verbal, con mención a Jesús y María, frente a los emisores laicos que solían ceñirse al signo de

47 Carta de 19 de julio de 1658, Cartas de sor María de Jesús de Ágreda y de Felipe IV, op. cit. (nota 38), t. II, p. 109.

48 Teresa de Jesús, op. cit. (nota 26, 1997), no 55, p. 156. "Esta carta dé a nuestro padre a recaudo, y si no estuviera ahí, no se la envíe sino con persona muy cierta, que importa", anota al término de otra a la madre María de San José, datada en Malagón a 15 de junio de 1576, ibidem, no 109, p. 291.

49 Así puede constatarse en las de Benedicta Teresa, AHN, Inquisición, leg. 3692', fols. 478-731. El formato cuarto es más habitual a partir del siglo XVIII, aunque anteriormente se documenta, por ejemplo, en un conjunto de cartas de súplica al Superintendente General de las Minas de Almadén (1685-1699), AHN, Fondos Contemporáneos, Minas de Almadén, Leg. 8492. Véase CAstillo Gómez, A.: “"Muchas cartas tengo escritas'. Comunicació epistolar i correu a l'Espanya moderna", en Iglesias FonsecA, J. A. (ed): Communicatio: un itineari històric, Murcia, Nausícaä, 2013, pp. 147-148.

50 Ana de San Bartolomé, por ejemplo, lo hizo cerca de 100 veces. Cfr. Ana de San Bartolomé, op. cit. (nota 27), p. 790.

51 Véase una reproducción del sello en Castillo interior. Teresa de Jesús y el siglo XVI. Catálogo de la exposición, Ávila, Catedral de Ávila, 1995, p. 241.

52 CAstillo Gómez, A.: “'El mejor retrato de cada uno'. La materialidad dela escritura epistolar en la sociedad hispana de los siglos XVI y XVII”, Hispania, LXV/3, núm. 221 (2005), p. 854. 
la cruz, a veces imperceptible ${ }^{53}$. Conforme a la tratadística epistolar, las expresiones de saludo y despedida dependían del tono de la carta y de la persona a la que iba destinada. Teresa de Jesús se hizo eco de ello en diferentes ocasiones, entre otras en una carta al padre Gracián (Toledo, 5 de septiembre de 1576) en la que le preguntó por el sobrescrito que debía poner en las misivas encaminadas a su valedor en Madrid: "No olvide vuestra paternidad de escribirme cómo se llama el hombre a quien yo he de guiar las cartas a Madrid, aquel criado de su padre. Mire no se le olvide, y decirme cómo le he de poner el sobrescrito, y si es persona a quien se pueden dar los portes" ${ }^{54}$.

En su epistolario se distingue, en efecto, entre el tratamiento de cercanía que utiliza en las cartas a sus iguales, frailes, monjas, familiares y conocidos ("Jesús sea con vuestra señoría", "Jesús sea con vuestra paternidad", "Jesús sea con ella, hija mía", "Jesús sea con vuestra reverencia" o "Jesús sea con vuestra merced"), y la forma más protocolaria que emplea cuando se dirige al rey ("A la sacra católica cesárea real majestad del rey nuestro señor") o a distintas autoridades eclesiásticas y civiles ("Al ilustrísimo señor y reverendísimo don Álvaro de Mendoza, obispo de Ávila, mi señor" o "Al ilustrísimo y reverendísimo señor don Teutonio de Braganza, arzobispo de Évora, mi señor" o "Muy ilustres señores"). En la despedida, hace uso del lenguaje de humildad y servidumbre característico de las epístolas conventuales femeninas y de otros escritos de religiosas ("indigna hija y súbdita de vuestra paternidad", "indigna sierva de vuestra reverencia", "sierva e hija y súbdita", "humilde sierva", "hija y sierva", "sierva, que a ti te ama" o "sierva indigna de vuestra merced").

En el plano gráfico, las cartas de las religiosas áureas, en cuanto que expresión de alfabetizaciones muy desiguales, no se compadecen fácilmente con las nomenclaturas paleográficas al uso, sobre todo por la habitual vinculación de estas a las modalidades empleadas en las escribanías cancillerescas y notariales, ni tampoco con las tipologías descritas coetáneamente en los manuales de escritura ${ }^{55}$. Más bien, presentan a menudo signos de cierto desorden escritorio y de algún apuro en la ejecución, rasgos que, según Armando Petrucci, serían fruto no sólo de la dificultad habida en el acceso y uso de la escritura, sino también de la fuerte emotividad contenida en dichos escritos $^{56}$. Esta circunstancia, sumada al tópico de la ignorancia femenina, explicable en una época que limitó el alfabetismo de las mujeres y les puso numerosos proble-

53 Sobre la pervivencia de la invocación cruciforme en la época moderna e incluso contemporánea, véase Pérez Herrero, E.: "La invocación simbólica o monogramática y la invocación verbal o explícita en las matrices de las actas notariales de los escribanos de Las Palmas en los siglos XVI al XIX custodiadas en el Archivo Histórico Provincial de las Palmas", Vegueta. Anuario de la Facultad de Geografía e Historia, 0 (1992), pp. 173-188; Romero Tallafigo, M., Rodríguez Liáñez, L., y Sánchez González, A.: Arte de leer escrituras antiguas. Paleografía de lectura, Huelva, Universidad de Huelva, 1995, p. 70; y LoRENZO CADARSO, P. L.: "Caracteres extrínsecos e intrínsecos del documento", en RiEsCo TERrERo, Á. (ed.): Introducción a la Paleografia y la Diplomática General, Madrid, Síntesis, 1999, p. 272.

54 Teresa de Jesús, op. cit. (nota 26, 1997), nº 118, p. 315.

55 Para la amplia producción de estos, Martínez Pereira, A.: Manuales de escritura de los Siglos de Oro. Repertorio crítico y analítico de obras manuscritas e impresas, Mérida, Editora Regional de Extremadura, 2006.

56 Petrucci, A.: Scrivere lettere. Una storia plurimillenaria, Roma-Bari, Laterza, 2008, pp. 101-102. En la misma línea Bartoli Langeli, A.: "La scrittura come luogo delle differenze", en Caffiero, M. y Venzo, M. I. (eds.): Scritture di donne. La memoria restituita. Atti del convegno, Roma, 23-24 marzo 2004, Roma, Viella, 2007, p. 55, habló de una escritura "atormentada y doliente". 
mas a la hora de expresarse por escrito, sirve para entender la disculpa por la letra empleada que apreciamos tanto en las cartas de las monjas, verbigracia el testimonio que sigue de sor María de Ágreda, como en las de otras mujeres del Barroco: "Señor: Mucho tiene Vuestra Majestad que perdonarme mis osadías y la mala letra, que, por no volver a trasladar la carta y estar con poca salud, va con muchas faltas" ${ }^{57}$. Esta vez pudo deberse a la delicada salud, del mismo modo que le sucedió a Teresa de Jesús en distintos momentos, con el agravante de que esta escribió la mayor parte de sus cartas en los últimos lustros de vida, es decir, cuando más delicada de salud estaba. En otras ocasiones, sin embargo, la calidad de la letra también se pudo ver afectada por distintos factores, ya fuera la hora a la que se escribía, frecuentemente la noche ${ }^{58}$, o la premura, máxime si se trataba de la respuesta a otra con el mensajero esperando ${ }^{59}$. Conviene, pues, apreciar estas y otras situaciones cuando nos enfrentamos a una letra carente de pericia para valorarla en su justa dimensión sin atribuirlo directamente a una escasa alfabetización.

Dirigiendo ahora la mirada a los autógrafos epistolares examinados, un primer punto a destacar es la variedad de ejecuciones y de rasgos personales que se detectan en ellos. Ambos fenómenos, estrechamente unidos, se corresponden con el contexto de multigrafismo relativo que existió en los siglos XVI y XVII ${ }^{60}$, en buena parte debido a la extensión del alfabetismo y, aún más, a la diversidad de vías de acceso a la escritura, propia del periodo ${ }^{61}$. En el corpus epistolar de las monjas áureas coexisten testimonios de sobrada competencia gráfica, como la cuidada y sosegada humanística cursiva de aire cancilleresco que utilizó Benedicta Teresa (Fig. 1) ${ }^{62}$, con otros donde se evidencia una mayor tensión a la hora de escribir, plasmada en letras más irregulares, angulosas y quebradas, según vemos en Ana de San Agustín, fundadora del convento de Valera de Abajo y compañera de Teresa de Jesús en la fundación de Villanueva de la Jara, ambos en la provincia de Cáceres ${ }^{63}$, o en Anastasia de la Encarna-

57 Carta de 1 de octubre de 1645, Cartas de sor María de Jesús de Ágreda y de Felipe IV, op. cit. (nota 38 ), t. I, p. 43. Para la misma disculpa en cartas de mujeres no religiosas, cfr. CAstillo Gómez, op. cit. (nota 52), pp. 872-874.

58 "La letra se escribió tan aprisa, y es, como digo, tal hora, que no la puedo tornar a leer", TERESA DE JESÚs, Carta a su hermano Lorenzo de Cepeda (Ávila, 23 de diciembre de 1561), op. cit. (nota 26, 1997), nº 2, p. 56; "Anoche le escribí otros renglones, y harto he hecho ahora, según la prisa que tengo en escribir éstos", Carta a la Madre María Bautista (Segovia, 16 de julio de 1574), ibidem, n 70, p. 187; "Escribo esta tan aprisa que no podré decir lo que quisiera, que me vino una visita forzosa ya que la quería comenzar, y es muy anochecido y hanla de llevar al recuero", Carta al padre Gracián (Toledo, 7 de diciembre de 1576), ibidem, n 159 , p. 426.

59 "Hoy víspera de la Concepción me envía las cartas el arriero y gran prisa por la respuesta", Carta a la Madre María de San José (Toledo, 7 de diciembre de 1576), ibidem, n 160, p. 429.

60 Ruiz García, E.: "La escritura humanística y los tipos gráficos derivados", en Riesco Terrero, op. cit. (nota 53), pp. 174-176.

61 Castillo Gómez, A.: Escrituras y escribientes. Prácticas de la cultura escrita en una ciudad del Renacimiento, Las Palmas de Gran Canaria, Gobierno de Canarias-Fundación de Enseñanza Superior a Distancia, 1997, pp. 308-314. En lo que concierne al aprendizaje de la escritura, Gimeno Blay, F. M.: "Aprender a escribir en el Antiguo Régimen”, en Escolano Benito, A. (dir.): Historia ilustrada del libro escolar en España. Del Antiguo Régimen a la Segunda República, Madrid, Fundación Germán Sánchez Ruipérez, 1997, pp. 291-314.

62 Al mostrale los papeles numerados que integran el expediente que le abrió la Inquisición, donde están sus cartas, reconoció "que todos ellos son escritos y firmados de su letra, firma y mano para el conde-duque", AHN, Inquisición, leg. $3652^{1}$, fol. 731 r.

63 De Ana de San Agustín he podido ver algunos de los autógrafos que se conservan en las Carmelitas Descalzas de Palencia y de Teruel gracias a las reproducciones que me proporcionó Deborá Dziabas Pereira, 
ción, priora del monasterio de la Ascensión en Lerma (Fig. 2) ${ }^{64}$. Con "trazos seguros y personales, reconocibles" ${ }^{65}$, escribió Teresa de Jesús, cuya letra es una humanística corriente con cierta propensión ascendente. De ejecución rápida y algo descuidada, contiene abundantes abreviaturas y ligados así como algunas particularidades: doble $i$ (corta y larga) siempre con punto, $r$ de martillete en posición inicial o las barras oblicuas utilizadas como signos de puntuación (Fig. 3) ${ }^{66}$. Una letra bastante característica, de aire arrebatado, que, junto a las razones aducidas anteriormente, puede deberse a sus problemas de salud, a la tardía edad en la que escribió la mayoría de sus cartas e incluso a la intensidad de su experiencia religiosa. Es visiblemente distinta a la ya comentada de Benedicta Teresa o a la de María de Ágreda. La de esta es una bastarda algo irregular, inclinada a la derecha y en la que destacan como rasgos singulares el pronunciamiento de los caídos frente a los astiles superiores apenas sobrealzados $(b$ o $t$ ) o la similar ejecución de $P$ y $R$, ya que esta es como la anterior más el apéndice del trazo medio de apoyo (Fig. 4$)^{67}$.

Es obvio que estas notas pueden y deben ampliarse y matizarse a medida que se hagan indagaciones más concretas y se amplíe el corpus. No obstante, la exploración efectuada permite apuntar algunas tendencias de carácter general. De un lado, es indiscutible que la correspondencia personal visibiliza un panorama gráfico mucho más rico y heterogéneo del que se percibe en otros estudios circunscritos a la documentación de tipo oficial y profesional. Esto, como señaló Petrucci a propósito del libro de cuentas de la tendera Maddalena en la Roma del siglo XVI, lleva al paleógrafo a "albergar dudas sobre la legitimidad y utilidad de su trabajo", dado que su método no alcanza siempre a nombrar y distinguir las grafías personales ${ }^{68}$. Y de otro, en el caso de las monjas carmelitas se aprecian algunas similitudes que nos llevan a pensar tanto en aprendizajes de ámbito conventual como en el uso de los escritos teresianos a modo de muestras caligráficas.

quien dedicó a esta monja su Trabajo de Suficiencia Investigadora, Autobiografia espiritual: Ana de San Agustín (1606 y 1609), Universidad de Alcalá, Departamento de Historia I y Filosofía, 2007. Para una relación de sus escritos, Rebollo Prieto, J.: Las escritoras de Castilla y León (1400-1800). Ensayo bibliográfico, Tesis Doctoral, UNED, 2006, pp. 48-53, http://www.uned.es/bieses/libros-pdf/TESIS\%20FINAL[1].pdf. (acceso: 6-10-2013).

$64 \mathrm{Al}$ margen de la carta reproducida, sobre sus escritos véase: Rebollo Prieto, op. cit. (nota 63), pp. 65-66.

65 Mas Arrondo, A.: “Acerca de los escritos autógrafos teresianos: 'Vida', 'Castillo interior' y 'Relaciones"”, en Ros GARCíA, S. (coord.): La recepción de los místicos Teresa de Jesús y Juan de la Cruz, Salamanca, Universidad Pontificia de Salamanca, 1997, p. 103. Sobre los autógrafos teresianos, véase el reciente repertorio de Álvarez, T. y Pascual, R.: Estudios teresianos, V, Autógrafos de Santa Teresa en Europa y América, Burgos, Monte Carmelo, 2014.

66 La carta que ilustra este pasaje presenta algunas mutilaciones marginales producidas seguramente al enmarcarla. Mientras que el primer folio se conserva en Alcalá de Henares, el segundo se halla en las Carmelitas Descalzas de San José de Zaragoza. Para la edición, TeRESA DE Jesús, Obras completas, op. cit. (nota 3), $\mathrm{n}^{\circ} 305$, pp. 1806-1809, e ID., op. cit. (nota 26, 1997), $\mathrm{n}^{\circ} 315$, pp. 819-824. Sobre los rasgos gráficos de su escritura, véase el sucinto análisis que Pedro C. Rojo Alique hace del folio $3 \mathrm{r}$ del autógrafo del Libro de las fundaciones (Biblioteca del Real Monasterio de El Escorial) en JAURALDE Pou, P. (dir.): Biblioteca de Autógrafos Españoles, I (Siglos XVI-XVII), Madrid, Calambur, 2008, p. 125; y Álvarez y Pascual, op. cit. (nota 65), pp. 48-52.

67 Véase el análisis paleográfico de Rojo Alique, en JAURALDE Pou, op. cit. (nota 66), p. 17.

68 Petrucci, A.: "Scrittura, alfabetismo ed educazione grafica nella Roma del primo Cinquecento", Scrittura e civiltà, 2 (1978), p. 167. 
Sobre este asunto es bien significativo el caso de Ana de San Bartolomé, quien aprendió a escribir a la edad de 30 años, mientras que a leer lo había hecho de niña ${ }^{69}$, convirtiéndose desde ese momento en secretaria de Teresa de Jesús, como esta anotó en una carta al padre Gracián, fechada en Ávila a 4 de diciembre de 1581: "Ana de San Bartolomé no cesa de escribir, harto me ayuda"70. De acuerdo con el testimonio que la beata Ana aportó en el proceso de beatificación de Teresa de Jesús, fue esta quien, en el verano de 1579, en Salamanca, le pidió que le ayudara a responder las muchas cartas que recibía. Al no saber escribir le dio como modelo "una carta de buena letra de una religiosa descalza" para que "de allí aprendiese", lo que nos advierte seguramente sobre una forma de aprendizaje practicada a menudo en los conventos; pero Ana le respondió que prefería hacerlo imitando su letra, como así fue:

Y la santa Madre luego escribió dos renglones de su mano y dióselos; y a imitación de ellos escribió una carta esta testigo aquella tarde a las hermanas de San José de Ávila. Y desde aquel día la escribió y ayudó a responder las cartas que la Madre escribía, sin haber, como dicho tiene, tenido maestro ni aprendido a escribir de persona alguna, ni haberlo aprendido jamás, y sin saber leer más de un poco de romance, y con dificultad conocía las letras de cartas; por do conoce ser obra de Nuestro Señor para que ayudase a la Madre en los trabajos y cuidados que por su amor pasaba con tanta alegría y regocijo ${ }^{71}$.

En materia de contenido, las cartas conciernen a asuntos tan diversos como lo fueron la dimensión humana, religiosa, social o política de la monja, las concretas motivaciones de cada epístola y la heterogeneidad de los destinatarios. Si tomamos como botón de muestra el epistolario de Ana de Jesús es claro el contraste entre las cartas que dirigió a Fr. Diego de Guevara y las destinadas a sor Beatriz de la Concepción. Mientras que en las primeras trata preferentemente de consejos espirituales, problemas con las fundaciones monásticas, la desconfianza hacia los padres generales del Carmelo o los avatares editoriales del Libro de Job de Fr. Luis de León y de la traducción al flamenco de las obras de Teresa de Jesús; en las misivas a la monja amiga adopta un tono más personal e íntimo, ocupándose de sentimientos, el sufrimiento por la distancia o los problemas de salud que tuvo en los últimos años de su vida ${ }^{72}$.

Puesto que esta pluralidad de asuntos y destinatarios es incompatible con analizar las cartas bajo patrones excesivamente rígidos, opto por centrarme en la producción, mejor dicho en parte de ella, de dos monjas que enuncian modelos epistolares distintos pero ambos plenamente representativos de la Contrarreforma: Teresa de Jesús y María de Ágreda. La primera encarna a la monja empeñada en la reforma religiosa quien halló en la correspondencia un medio privilegiado para llevarla adelante; en

69 Urkiza, J.: "Introducción”, en AnA de SAn Bartolomé, op. cit. (nota 27), p. 13.

70 Teresa de Jesús, op. cit. (nota 26, 1997), nº 424, p. 1080.

71 Procesos de beatificación y canonización de Sta. Teresa de Jesús, editados y anotados por el padre Silverio de Santa Teresa, Burgos, Tipografía de "El Monte Carmelo", 1934 (Biblioteca Mística Carmelitana, 18), p. 173. Además, la declaración servía para afianzar la santidad pues se contiene en la respuesta a la novena pregunta del interrogatorio, a saber, "si saben que Nuestro Señor obró por medio e intercesión del cuerpo o reliquias de la dicha Madre después de muerta algunos milagros".

72 TORRES, op. cit. (nota 29), pp. 15-41. 
tanto que la segunda, en su carteo con Felipe IV, se ajusta más a la figura de la "divina madre" dada su labor de consejera política y espiritual del rey ${ }^{73}$.

\section{4. "PARA QUE NO SE ENFRÍE LA CARIDAD”: LA CORRESPONDENCIA DE TERESA DE JESÚS}

El epistolario teresiano se aproxima a las $500 \operatorname{cartas}^{74}$, pero algunos de sus editores han estimado que pudo escribir entre 10 y 25.000, a razón de 2 a 5 diarias ${ }^{75}$. La práctica epistolar de Teresa de Jesús prácticamente fue inasequible al desaliento y tan sólo se vio mermada por sus problemas de salud. Ana de San Bartolomé, su íntima colaboradora, dijo de ella que "le acaecía estar despachando y escribiendo cartas hasta las dos de la mañana"76; en tanto que Ana de Jesús, otra de sus discípulas, anotó que le escribía "muy a menudo" y que no dejó de hacerlo "hasta la última semana que vivió"77. Su apego a la escritura transita a menudo entre la pasión y el desasosiego, aunque a veces mostrara cierto pesar por todo la "baraúnda" de cartas que debía escribir, cuando tan necesario le era ese tiempo para sus obras espirituales:

¡Mire si obedezco bien! Cada vez pienso que tengo esta virtud, porque de burlas que se me mande una cosa la querría hacer de veras, y lo hago de mejor gana que esto de estas cartas, que me mata tanta baraúnda. No sé cómo me ha quedado tiempo para lo que he escrito, y no deja de haber alguno, para José [Jesucristo], que es quién da fuerzas para todo $^{78}$.

Si espigamos en su correspondencia hallaremos continuas referencias a dicha actividad así como a los duplicados que solicitaba a sus amanuenses, especialmente de las cartas que enviaba por dos o más correos o de las que dirigía al padre Gracián ${ }^{79}$. También fueron bastante comunes las precauciones que tomó en relación con la lectura

\footnotetext{
73 Sigo la propuesta de Scattigno, op. cit. (nota 37), pp. 313 357, donde compara las figuras de Maria Maddalena de' Pazzi y Caterina de' Ricci. Si la primera se dirigió preferentemente a la comunidad religiosa, la segunda destacó como consejera de hombres importantes.

74 De las dos ediciones con que he trabajado, la de Tomás Álvarez se compone de 468 cartas y 18 fragmentos dispersos, mientras que la dirigida por Alberto Barrientos se queda en 450 y 24 fragmentos.

75 Rodríguez Martínez, L., y Egido, T.: “Epistolario. Introducción”, en Teresa DE Jesús, Obras completas, op. cit. (nota 3), p. 1218.

76 Procesos de beatificación y canonización de Sta. Teresa de Jesús, op. cit. (nota 71), p. 286.

77 Cfr. Álvarez, T.: "Introducción”, en Teresa de Jesús, op. cit. (nota 26, 1997), p. 33.

78 Teresa de Jesús: Carta al padre Jerónimo Gracián (Toledo, 31 de octubre de 1576), ibidem, n 138, pp. 378-379. Carta enviada junto al manuscrito ya muy avanzado del Libro de las fundaciones.

79 Ibidem, pp. 18-19 (“Introducción”) y, como muestra, las cartas no. 14, 103, 147, 230, 280 y 281.
} 
de algunas ${ }^{80}$, al igual que sus ruegos para que se quemaran otras ${ }^{81}$, casi siempre las más comprometidas de cara a su incómoda relación con los padres carmelitas, recelosos de la reforma espiritual que estaba llevando a cabo. A uno de estos episodios se refirió precisamente Ana de Jesús: "Y por haberme tratado de muchas cosas en las cartas que me había escrito, viendo una vez algo revuelta la religión y contienda de prelados, porque aún no los teníamos de nuestros descalzos como ahora, me envió mandar la Madre quemase todas sus cartas" $"$.

Como se ha dicho anteriormente, la parte más granada del epistolario corresponde al período de su madurez, época a la que también pertenecen sus obras mayores. Fueron años de intensa experiencia espiritual que ella quiso extender y compartir a través de la escritura y, en particular, de las cartas. De ahí sus habituales excusas por no responder siempre inmediatamente a las misivas que recibía o por hacerlo con menor extensión de la debida dada su delicada salud y la mucha fatiga que iba acumulando: "No escribo ahora más largo, porque hoy he escrito mucho y es tarde" 83 , o "Porque a la madre priora escribo muy largo (que he tenido a dicha estar sin otras cartas hoy por poderlo hacer, y ella dirá a vuestra merced lo que aquí falta), no digo más de suplicarle no me deje de escribir alguna vez, que me consuelo mucho" 84 . Aunque gustaba de escribirlas de propia mano, por el mismo motivo a menudo tuvo que valerse de distintas secretarias: la sobrina Beatriz de Jesús, a su paso por Toledo; Ana de San Pedro y sus sobrinas Isabel de San Pablo y Teresita, hija de su hermano Lorenzo, cuando paraba en Ávila; y Ana de San Bartolomé, en sus desplazamientos. La primera vez que lo hizo fue a finales de 1568, tras la grave enfermedad que contrajo en Río de Olmos (Valladolid), mientras que a partir de 1577, cuando su estado empeoró, se hizo bastante habitual ${ }^{85}$.

\footnotetext{
80 "Mire que son diferentes los entendimientos y que nunca los prelados han de ser tan claros en algunas cosas; y podrá ser que las escriba yo de tercera persona o de mí; y no será bien que las sepa nadie, que va mucha diferencia de hablar conmigo misma (que es eso vuestra paternidad), a otras personas, aunque sean mi misma hermana; que, como no querría que ninguno me oyese lo que trato con Dios ni me estorbase a estar con Él a solas, de la misma manera es con Pablo...", Carta al padre Gracián (Toledo, noviembre de 1576), ibidem, n 141, p. 384. Pablo es uno de los heterónimos que emplea para referirse a Jerónimo Gracián. La correspondencia con éste abunda en estos recursos como él mismo advirtió: "cuando nos escribimos la madre Teresa y yo, por manera de cifra, mudábamos los nombres; y gatos llamábamos algunas veces a los frailes calzados". GRACIÁN DE LA MADRE DE Dios, J.: Peregrinación de Anastasio, edición de Giovanni Maria Bertini, Barcelona, Juan Flors, 1966, diálogo 16, p. 265. Sobre el uso de la escritura cifrada en el epistolario teresiano, véase: Cuevas García, C.: "Los criptónimos en el epistolario teresiano", en Egido Martínez, T., García de la Concha, V., y GonzÁlez de Cardedal, O. (eds.): Actas del Congreso Internacional Teresiano, Salamanca, Ediciones Universidad de Salamanca, 1982, t. II, pp. 557-580; y Álvarez, op. cit. (nota 77), pp. 19-24.

81 "Jesús sea con vuestra paternidad. Después de escribir la que va con ésta, hoy día de la Ascensión me han traído sus cartas por la vía de Toledo, que me han dado harta pena. Yo le digo, mi padre, que es cosa temeraria. Roma vuestra paternidad luego ésta", Carta al padre Gracián (Ávila, 8 de mayo de 1578), TERESA DE JESÚs, op. cit. (nota 26, 1997), n 245, p. 650.

82 Álvarez, op. cit. (nota 77), p. 33. De hecho, en la obra de Torres, op. cit. (nota 29) no se incluyen las cartas que escribió a Teresa de Jesús antes de la muerte de esta porque ella misma las mandó quemar (p. 12).

83 TeResa DE Jesús: Carta a su hermana doña Juana de Ahumada (Toledo, 19 de octubre de 1569), op. cit. (nota 26, 1997), n 22, p. 95.

84 Carta al padre García de San Pedro (Medina, [agosto] de 1571), ibidem, no 35, pp. 123-124.

85 Álvarez, op. cit. (nota 77), pp. 15-19.
} 
Escritas en estilo directo y coloquial ${ }^{86}$, las cartas fueron el mejor camino para ejercer su magisterio espiritual, lo que tempranamente se reveló, como también aconteció con las cartas de san Juan de la Cruz, en el papel ejemplar de las mismas, incluso en términos gráficos, según queda anotado más arriba. Otro aspecto aún más relevante del valor que coetáenos y gentes de épocas posteriores dieron a los escritos de Teresa de Jesús concierne a su veneración como reliquias. No ya porque se llevaran en el corazón, como dijo de ciertas cartas el padre Francisco Ortiz en sus Epistolas familiares $(1552)^{87}$; sino por su conservación devota, como la que Jerónimo Gracián refiere de Felipe II, la princesa doña Juana, los duques de Alba y de otros miembros de la nobleza, quienes, tras leerlas, gustaban de guardar sus cartas "como una viva doctrina para su bien"88; y especialmente, por la capacidad de obrar milagros que las cartas y otros escritos llegaron a tener, sobre todo si conservaban su olor:

También se acuerda que, estando la santa Madre en una fundación, se le ofreció escribir a la prelada de esta casa [convento de Ávila] una memoria en exhortación a la virtud de la pobreza del espíritu, la cual mandaba se leyese a las hermanas y después se guardáse en el arca de las tres llaves. No advirtiendo desde más de tres años después de la fecha de la carta, se la dieron a esta testigo, entre otras cartas viejas, y esta testigo las guardó en una caja adonde tenía otras cosillas; y yendo un día a buscar cierta cosa que tenía en ella, siendo ya muerta la Madre más había de dos años, le dio tan grande olor de la Santa, que es muy conocido entre las hermanas y las que ya han tratado su cuerpo, que la causó tan grande admiración que le obligó a leer todas las cartas hasta que halló la de la santa Madre; y a esta declarante le pareció que era milagro por haber mandado la Santa se guardase en el arca de las tres llaves y ser carta de mucha importancia, y no querer Nuestro Señor que se perdiese; y por muchos día quedó oliendo la caja y lo que en ella estaba; y por cosa de admiración lo dijo luego a la madre priora $\mathrm{y}$ a las hermanas ${ }^{89}$.

Claro que, en determinados casos, una consecuencia de este fervor fue tanto la dispersión como, todavía más grave, su fragmentación, debido al deseo de conventos y particulares de atesorar un pedazo de papel escrito por la madre Teresa ${ }^{90}$. Esto, lejos

\footnotetext{
86 Mancini, G.: "Tradición y originalidad en el lenguaje coloquial teresiano", en Egido Martínez, García DE LA Concha, y González de CARDEDAl, op. cit. (nota 80), t. II, p. 492.

87 “Así que, por más astroso que yo sea, mientras a Vm. escribiere las palabras que son de Dios, me gozaré de que se tengan las cartas como reliquias, no tanto en el cofre, cuanto en el corazón", anota en la epístola VIII dirigida a su cuñada Juana Arias. Cfr. OrTíz, F.: Epistolas familiares, Zaragoza, Bartolomé de Nájera, 1552. Véase también en Epistolario español. Colección de cartas de españoles ilustres antiguos y modernos, edición de Eugenio Ochoa, Madrid, Ediciones Atlas, 1965, t. I (BAE, 13), p. 272.

88 Gracián de la Madre de Dios, J.: Diálogos sobre la muerte de la M. Teresa de Jesús, introducción del padre Silverio de Santa Teresa, Burgos, Tipografía de "El Monte Carmelo", 1913, p. 164. Cfr. Teresa de Jesús, Obras, editadas y anotadas por el padre Silverio de Santa Teresa, t. VII: Epistolario (I), Burgos, Tipografía de "El Monte Carmelo", 1922 (Biblioteca Mística Carmelitana, 7), p. VIII.

89 Procesos de beatificación y canonización de Sta. Teresa de Jesús, op. cit. (nota 71), p. 181 (Declaración de la monja Petronila Bautista). Jerónima del Espíritu Santo dijo, a su vez, que, entre otros papeles, había visto "una carta escrita de su mano de la dicha madre Teresa para la dicha madre Ana de Jesús, que toda ella está bañada de este mismo óleo sin haber llegado a otra cosa que pudiese causar aquello, sino sólo haberla escrito la dicha Madre y pasado la mano por encima", ibidem, p. 325.

90 SÁnchez-Castañer, F.: "Las cartas hispanoamericanas de Santa Teresa de Jesús", Anales de Literatura hispanoamericana, 11 (1982), p. 173. Similar fue el caso de las cartas de Caterina de'Ricci. Cfr. Scattigno,
} 
de ser reprobado, fue aplaudido y recomendado por gentes tan significadas como el padre José Fresa, predicador del convento zaragozano de Nuestra Señora del Buen Parto: "Porque no peligrassen reliquias tan preciosas, entró mui cuidadoso el zelo de sus hijos a repartirnoslas" $"$.

El suyo no es un epistolario doctrinal ni siquiera únicamente espiritual, aunque no falten páginas de esta índole, sino la evidencia más palmaria del valor que para ella tuvo la correspondencia en cuanto que forma de comunicación cotidiana. La entendió como un instrumento idóneo para llevar adelante su actividad reformadora en el ámbito del Carmelo, de ahí que sus cartas abunden en las gestiones realizadas en cada fundación, en especial en las que dirige a Gracián, y en el intercambio de noticias entre las distintas monjas a fin de reforzar la solidaridad que debía haber entre ellas, como la misma Teresa recomendó en más de una ocasión. Así, en una a la madre María de San José, carmelita descalza en Sevilla, le pidió expresamente que le "escriba por todas las vías que pudiere para que yo sepa siempre como están" ${ }^{92}$. Ana de San Bartolomé se refirió también a esto en una carta a la madre Catalina Bautista, escrita desde Amberes a finales de 1625, en la que puso en boca de Teresa de Jesús la siguiente respuesta a una priora que le había preguntado por qué escribía tanto a las monjas: "Porque deseo que vosotras lo hagáis y os comuniquéis las unas con las otras para que no se enfríe la caridad"93. Esta misma razón explica la lectura comunitaria que se hacía de sus cartas y de otros escritos en los conventos carmelitas, según apunta la declaración ya citada de la monja Petronila Bautista ${ }^{94}$. A veces se hizo contra su propio parecer, sobre todo cuando se trataba de las cartas más confidenciales y comprometidas en su relación con los superiores carmelitas, como le indicó a Jerónimo Gracián en noviembre de 1576:

Mas ¡qué pesada voy! No le pese a mi padre de oír estas cosas, que estamos vuestra paternidad y yo cargados de muy gran cargo y hemos de dar cuenta a Dios y al mundo; y porque entiende el amor con que lo digo, me puede perdonar y hacerme la merced que le he suplicado de no leer en público las cartas que le escribo ${ }^{95}$.

Sin ser las de Teresa misivas que respondan al prototipo de las cartas espirituales ${ }^{96}$, modalidad más visible en las que escribió a Gracián, las mismas fueron difundidas y

\footnotetext{
op. cit. (nota 37), pp. 318-319.

91 Cartas de la gloriosa madre Santa Teresa de Jesús, con notas del Excelentísimo y Reverendísimo don Juan de Palafox y Mendoza, obispo de Osma, del Consejo de Su Majestad; recogidas por orden del Reverendísimo padre Fray Diego de la Presentación, General de los Carmelitas Descalzos, Zaragoza, Diego Dormer, 1658, t. I, fol. [థ3v], “Aprovación”.

92 Teresa DE Jesús: Carta a la M. María de San José (Malagón, 15 de junio de 1576), en ID., op. cit. (nota $26,1997), n^{\circ} 109$, p. 289. De este tipo son también las cartas de Ana de Jesús, sobre todo las que escribió entre 1602 y 1610, cuando llevó a cabo las primeras fundaciones en Francia y Flandes. $C f r$. ToRREs, op. cit. (nota 29), p. 17.

93 ANa de SAn Bartolomé, op. cit. (nota 27), carta 637, p. 1586.

94 Un caso bastante similar y coetáneo aconteció con la lectura comunitaria de las cartas de la monja Caterina de' Ricci en el monasterio de San Vincenzo en la época del proceso de canonización de esta religiosa. Cfr. Scattigno, op. cit. (nota 37), p. 319.

95 TeResa DE Jesús, op. cit. (nota 26, 1997), n ${ }^{\circ}$ 141, p. 384. Se trata de la misma carta en la que también le expuso otras precauciones a propósito de la lectura de sus misivas (véase nota 80).

96 Prosperi, A.: "Lettere spirituali”, en Scaraffia y ZarRi, op. cit. (nota 2), pp. 227-251.
} 
leídas como modelos a seguir, es decir, como testimonios de la veneración tributada a la monja. Buena cuenta de ello es la temprana fecha en la que se pensó en darlas a la estampa ${ }^{97}$, poco después de su muerte, acaecida en 1582 . La primera idea la tuvo el padre Gracián, quien ya en sus Diálogos sobre la muerte de la Madre Teresa (c. 1584) hizo referencia a que dicha obra constituiría "un libro de los más provechosos e deleitosos que hubiese"98, sumándose así a la estela de otras iniciativas similares ${ }^{99}$. Tres años después el jesuita Francisco de Ribera incluyó algunas cartas extractadas en su biografía de Teresa de Jesús ${ }^{100}$, objeto de ampliación en el manuscrito de Gracián, Escolias y adiciones al libro de la Vida de la Madre Teresa de Jesús, que compuso el padre doctor Ribera, donde volvió sobre el interés que podía tener la edición impresa, aunque todavía la desaconsejara por el tono confidencial de algunas cartas:

para cómo me había de haber con algunas almas, me avisaba con cartas [la Madre Teresa], de las cuales guardé muchas, de que tengo un libro de tres dedos de alto, que aunque [no] es bien se publiquen por haber en ellas cosas muy particulares que es bien se guarden en secreto ${ }^{101}$.

La senda estaba marcada. Tras la publicación coyuntural de dos cartas de Teresa a Felipe II intercediendo a favor de Gracián, incluidas en la biografía que de este escribió Andrés del Marmol, Excelencias, vida y trabajos del padre fray Gerónimo Gracián de la Madre de Dios, carmelita (Valladolid, Francisco Fernández de Córdoba, 1619), el proyecto del epistolario impreso se retoma con fuerza a partir del 22 de abril de 1652, cuando el general de los Carmelitas Descalzos ordena la localización y recogida de los testimonios que habían de conformarlo:

Por quanto será de mucha gloria de nuestra Santa Madre Teresa de Jesús y aprovechamiento espiritual de las almas el que todos puedan gozar de la celestial doctrina que muchas de sus cartas, que hoy se conservan en España, contienen, y para que

97 Este vínculo entre la devoción y la difusión impresa de las cartas es algo que la misma Teresa de Jesús advirtió a propósito de una misiva de la monja Isabel de San Francisco: "Devoción me ha puesto esta carta de San Francisco, que se podía imprimir", Teresa de Jesús: Carta a la madre María de San José, (Toledo, 7 de diciembre de 1576), en ID., op. cit. (nota 26, 1997), nº 160, p. 429.

98 Gracián de la Madre de Dios, J.: Diálogos sobre la muerte de la Madre Teresa de Jesús (c. 1584). Cfr. Álvarez, op. cit. (nota 77), p. 38.

99 Es el caso de las cartas de Catalina de Siena, de las que 31 vieron la tipografía en 1498 (Bolonia, Fontesi) antes de la edición veneciana de Aldo Manuzio en 1500, que sirvió de base para otras posteriores así como para la traducción al castellano por expreso deseo del Cardenal Cisneros, quien dispuso su publicación en Alcalá en el taller de Arnao Guillén de Brocar en 1512. Véase Epistolario de Santa Catalina de Siena: espíritu y doctrina, edición de José Salvador y Conde, Editorial San Esteban, 1982, pp. 216-217. Coetánea a la princeps de las cartas de Teresa de Jesús fue la publicación, por iniciativa de Gian Franco Loredano, de Lettere familiari e di complimento (1650) de Arcangela Tarabotti, aunque se trata de un epistolario orientado más a la actividad literaria de esta monja. Cfr. WeAVER, op. cit. (nota 2), p. 270.

100 Ribera, F. DE: La vida de la madre Teresa de Jesús, s. 1.: s. n., 1587.

101 Gracián de la Madre de Dios, J.: Escolias a la Vida de Santa Teresa compuesta por el P. Ribera, edición de Juan Luis Astigarraga, Roma, Instituto Histórico Teresiano, 1982, p. 90. 
puedan andar en manos de todos con facilidad, será medio muy a propósito el darlas a la estampa ${ }^{102}$.

Con ese fin mandaron que todos los religiosos y religiosas notificaran "las cartas que supieren que hay, fuera y dentro de la religión, de nuestra gloriosa Madre santa Teresa de Jesús" al respectivo Provincial, para que este encargara la copia autorizada de las mismas a fin de remitirlas al General de la orden ${ }^{103}$. Los dos tomos de la primera parte del epistolario teresiano vieron la luz en el año 1658 en el taller zaragozano de Diego Dormer a partir de la selección realizada por el padre Diego de la Presentación y con los comentarios de Juan de Palafox y Mendoza, obispo de Osma, confirmándose la intervención masculina, especialmente de religiosos, que se ha señalado de otros epistolarios coetáneos de monjas italianas ${ }^{104}$. De inmediato, la obra se tradujo a otras lenguas y gozó de distintas reediciones, dando cuenta así de un notable suceso editorial, corroborado en 1674 con la edición, en Bruselas, de un nuevo tomo compuesto por otras 108 cartas más, al que un siglo después, en 1771, se sumarían otros dos: el $3^{\circ}$ con 82 cartas más y el $4^{\circ}$ con otras 75 y un elevado número de fragmentos ${ }^{105}$.

En la carta de Juan de Palafox y Mendoza al padre Diego de la Presentación, que forma parte de los preliminares de la princeps, el obispo de Osma justificó la edición "para pública utilidad de la Iglesia, porque en cada una de ellas se descubre el admirable espíritu de la Virgen prudentíssima". Añadió que, mientras otras obras de la santa, como el Camino de Perfección o Las Moradas, eran modelos para una vida interior conforme a Dios, el epistolario enseñaba a vivir "en esta exterior, unos con otros", es decir, el comportamiento cristiano en el mundo, ya que "con lo que dice en ellas nos alumbra de lo que devemos aprender, y con lo que estava obrando al escrivirlas de lo que devemos obrar" ${ }^{106}$. Dicha motivación resume bastante el propósito del epistolario y sobre todo la lectura que los coetáneos hicieron de él.

\section{CARTAS DE UNA “DIVINA MADRE”: MARÍA DE ÁGREDA Y FELIPE IV}

Si el epistolario de Teresa constituye un claro testimonio del valor asignado a la correspondencia en el devenir cotidiano de la reforma por ella emprendida y en la sociabilidad carmelita, el de María de Ágreda con Felipe IV se acomoda al patrón espiritual de las "divinas madres", esto es, las monjas que por su referencia moral fueron frecuentemente consultadas por reyes y hombres importantes ${ }^{107}$. En el caso que nos ocupa, dicha relación ha merecido distintas calificaciones: mientras que algunos

\footnotetext{
102 Teresa de Jesús: Obras, edición del padre Silverio de Santa Teresa, t. VII: Epistolario, Burgos, Monte Carmelo, 1915 (Biblioteca Mística Carmelitana, 7), p. LXVIII. Cfr. Álvarez, T.: "Introducción”, en Teresa DE Jesús, op. cit. (nota 26, 1997), p. 41.

103 Ibidem.

104 Prosperi, op. cit. (nota 96), p. 228.

105 Álvarez, op. cit. (nota 77), pp. 36-44.

106 Cartas de la gloriosa madre Santa Teresa de Jesús, op. cit. (nota 91), t. I, fol. A $_{2 \mathrm{v}}$.

107 Véase al respecto Prosperi, op. cit. (nota 96), pp. 227-251.
} 
autores la han presentado como el testimonio de la dependencia emocional del rey hacia la monja, otros han cargado las tintas en los objetivos políticos que ella podría albergar, llegando a involucrarla en la conspiración para derrocar al conde-duque ${ }^{108}$.

A diferencia de la andariega Teresa de Jesús, la monja concepcionista vivió encerrada entre los muros del convento de Ágreda desde su ingreso en 1618, a la edad de 16 años, hasta su muerte el día 24 de mayo de 1665. Su trato con la escritura corresponde al de una persona interesada en la función comunicativa de la misma y en su valor como extensión del desgarre espiritual y físico de cada vivencia mística. Su correspondencia con Felipe IV, con quien llegó a escribirse más de 600 cartas a lo largo de 22 años, es el resultado de un intercambio obligatorio y desigual, visible en el estilo de ambos corresponsales, dado que fue el rey quién lo comenzó y quién decidió los asuntos a tratar. Según dejó escrito sor María en una nota previa, el carteo con el soberano tuvo origen en la visita que este le hizo en el verano de 1643, meses después de haber destituido al conde-duque, cuando iba camino del frente de Cataluña:

Pasó por este lugar y entró en nuestro convento el Rey nuestro señor, a 10 de julio de 1643, y dejóme mandado que le escribiese; obedecíle, y en seis o siete cartas le dije que oyese a los siervos de Dios y atiendiese a la voluntad divina que por tantos caminos se le manifestaba... ${ }^{109}$.

Su confesor Francisco Andrés de la Torre, el que más importancia tuvo en la vida de sor María, jugó también un destacado papel en los que concierne a la correspondencia con Felipe IV. Fue él quien animó a la monja a que mantuviera dicho intercambio e incluso le mandó sacar copia de dicha correspondencia contra el parecer del soberano, más partidario del carácter absolutamente privado y secreto de dicha relación dado el elevado tono político de las confidencias mantenidas con la religiosa soriana, como le hizo notar desde el comienzo: "Sor María de Jesús: Escríboos a media margen, porque la respuesta venga en este mismo papel, y os encargo y mando que esto no pase de vos a nadie" 110 . Otras veces, sin embargo, las materias a tratar no se confiaron a la correspondencia ordinaria sino que se reservaron a otros papeles, como sucedió con las revelaciones de las almas de la reina Isabel y del príncipe Baltasar Carlos ${ }^{111}$.

En el momento de iniciarse la correspondencia, la monja era ya una celebridad espiritual, siendo esto lo que motivó que el rey acudiera a ella como consejera y mediadora ante Dios a causa de los numerosos problemas que aquejaban a la Monarquía, como el propio Felipe IV le confesó en la carta, antes citada, que le escribió desde Zaragoza poco tiempo después del primer encuentro, el día 4 de octubre: "Desde el día que estuve con vos, quedé muy alentado por lo que me ofrecísteis rogaríais a Nuestro Señor por mí y por los buenos sucesos de esta Monarquía, pues el afecto con

108 Silvela, F.: "Bosquejo histórico", en Cartas de la Venerable Madre Sor María de Ágreda, op. cit. (nota 38), t. I, pp. 204-216; Seco Serrano, C.: "La Madre Ágreda y la política de Felipe IV”, en La Madre Ágreda: una mujer del siglo XXI, Soria, Universidad Internacional Alfonso VIII, 2000, pp. 11-23; y Marañón, G.: El conde-duque de Olivares. La pasión de mandar, Madrid, Espasa-Calpe, 1936, pp. 444-445.

109 Cartas de sor María de Jesús de Ágreda y de Felipe IV, op. cit. (nota 38), t. I, p. 3.

110 Carta del Rey (Zaragoza, 4 de octubre de 1643), ibidem, t. I, pp. 3-4.

111 Baranda, C.: "Introducción”, en María de Jesús de Ágreda, op. cit. (nota 38), p. 29. 
que os reconocí entonces, a lo que me tocaba, me dio gran confianza y aliento" 112 . Aceptada la obligación, María de Ágreda entiende esa relación epistolar con el mismo sentido que había dado a su obra mística, con la que comparte el lugar común de la ignorancia femenina:

Es tan grande el [encogimiento] que tengo que necesito, a el tiempo de escribirlas, olvidar que soy mujer ignorante y acordarme que el Altísimo es poderoso (como dicen las Divinas Escrituras) para hacer de piedras hijos de Abraham y sacar óleo del guijarro, y puede concurrir mis palabras dándolas virtud y eficacia ${ }^{113}$.

Si el mandato divino, junto a la mediación del confesor, lo invocó a la hora de escribir una obra como la Mística ciudad de Dios ${ }^{114}$, el imperativo de la obediencia al soberano le sirvió para vencer la timidez y corresponderle como "como sierva fiel" 115 . Se dispuso entonces a interceder ante el Todopoderoso a fin de aliviar al soberano en sus tribulaciones y guiarle para que enmendara los erráticos caminos de la Monarquía católica, para que uno y otros se acomodaran más a la voluntad divina:

y como está en su diestra [la de Dios] nuestra buena suerte y en su poder nuestras victorias, presento a Su Majestad los aprietos de esta Monarquía, y le suplico nos mire con ojos de piadoso padre y como a profesores de su fe santa; y para más obligarle, en nombre de Vuestra Majestad, le ofrezco la enmienda de las costumbres y vicios generales que tienen contaminada a España, y la mudanza de los trajes, que son los que fomentan el fuego de este incendio; y si desenojásemos al Señor con la enmienda y le tenemos por amigo, estará la Monarquía de Vuestra Majestad amparada, defendida y bien patrocinada ${ }^{116}$.

La Monarquía pasó por un auténtico calvario entre 1644 y 1649 . A los problemas políticos suscitados en Flandes y con el rey de Francia, arrastrados de la etapa del conde-duque, se le sumaron un cúmulo de infortunios: la muerte de la reina Isabel de Borbón (10-X-1644), primera esposa de Felipe IV, la de su hermana María (13V-1646), emperatriz de Alemania, y la del príncipe Baltasar Carlos (9-X-1646), lo que dejaba al rey sin un incipiente colaborador y al reino sin heredero. En esas circunstancias, arreciaron las consultas políticas y espirituales del monarca a pesar de que este, en muchos casos, no siguió los consejos de la monja, con no poco malestar de esta. Debido a esto sor María estuvo tentada, en distintos momentos, de abandonar la relación epistolar, como le hizo saber por carta a don Francisco de Borja, hijo del virrey de Aragón y capellán de las Descalzas Reales, en alguna ocasión:

112 Cartas de sor María de Jesús de Ágreda y de Felipe IV, op. cit. (nota 38), t. I, p. 4.

113 Carta de 6 de marzo de 1648, ibidem, p. 141.

114 Castillo Gómez, op. cit. (nota 24), pp. 185-200.

115 Ambos entrecomillados proceden de la primera carta, fechada a 16 de julio de 1643. Cfr. Cartas de la Venerable Madre Sor María de Ágreda y del señor rey don Felipe IV, op. cit. (nota 38), t. I, p. 411.

116 Carta de 14 de septiembre de 1643, ibidem, pp. 413-414. 
Unos caballeros deste lugar han venido de esa Corte y me han dicho que el Rey anda divertido y que en palacio tiene esperanzas de sucesión; helo sentido de manera que, acordándome de lo que Moisés hizo cuando estuvo en el monte recibiendo la ley del Señor, cuando descendió del monte y vio que habían idolatrado y no aguardado la ley, rompió las tablas. Diferente sujeto soy yo que Moisés, pues soy un gusano y la menor de sus criaturas, pero viendo lo que he hecho con este señor y lo que le he dicho y con lo que él ha sabido, me ha dado ímpetu de romper todas las cartas suyas y mías que tengo los traslados; más pecadora soy yo, pero como este sujeto ha sido tan avisado, prevenido y llamado de Dios, muero sabiendo que no hace lo que le conviene ${ }^{117}$.

Más adelante, en otra carta del 14 de enero de 1656, vuelve a manifestar que prosigue la correspondencia muy a su pesar, por dos razones: "la primera porque me han dicho que está con sus mocedades antiguas y que le habían herido", refiriéndose a los rumores sobre la nueva amante del monarca; y la segunda, "porque veo que esta Corona está en gran peligro", imponiéndose su sentido del deber: "y yo no puedo hacer nada sino llorar y afligirme y escribir claro, y es hablar con un roble y diamante" 118 . La suya es, por tanto, una correspondencia de índole política y espiritual, toda vez que el buen gobierno de la Monarquía era inseparable del comportamiento católico que se esperaba del soberano. Esto explica que en este epistolario no se encuentren demasiados datos referidos a batallas o asuntos cortesanos ni se descienda a registros cotidianos, a diferencia, por ejemplo, de lo que sí acontece en la correspondencia del rey con la condesa de Paredes de Nava o en la de sor María con los Borja ${ }^{119}$.

Nacida a petición del monarca, la correspondencia fue evolucionando hacia un trato más cercano fruto de la estima que el rey tenía a la monja, a la que incluso llegó a tratar de amiga, como en una carta de enero de 1649 en la que le ofreció su apoyo en el juicio por traición contra el duque de Híjar: "En lo que toca a la materia del duque de Híjar, podéis perder todo cuidado, pues con decir que os conozco lo digo todo; y asegúroos, que lo que vos me habéis fiado a mí ni ha salido ni saldrá jamás de mi corazón, que sé ser buen amigo de mis amigas" ${ }^{120}$. Si descendemos a otros rasgos internos del epistolario, las cartas del último período muestran una prosa más refinada. Es lógico que sea así dado que en esa etapa la religiosa estaba entregada a la escritura de la Mística Ciudad de Dios, cuya maduración compartió con el rey; pero, además, porque a partir de 1648 el contenido de las misivas evoluciona hacia un estilo más elaborado, literario y metafórico. En consonancia con su mayor interés por la conver-

117 María de Jesús de Ágreda: Carta del 12 de junio de 1648, en Id., op. cit. (nota 38, 1991), p. 259. Todavía en enero de 1656 insiste en ello: “Ahora sólo digo que la correspondencia del Rey se continúa muy a mi pesar".

118 Ibidem, pp. 260-261.

119 Pérez Villanueva, J.: Felipe IV y Luisa Enríquez Manrique de Lara, condesa de Paredes de Nava. Un epistolario inédito, Salamanca, Caja de Ahorros y Monte de Piedad de Salamanca, 1986; y BARANDA LETURIO, op. cit. (nota 39), pp. 13-32.

120 Cartas de sor María de Jesús de Ágreda y de Felipe IV, op. cit. (nota 38), t. I, p. 176 (Madrid, 20 de enero de 1649). Para el sentido barroco de la amistad y el caso específico de la relación entre Felipe IV y María de Ágreda, remito a Morte Acín, op. cit. (nota 32), pp. 252-259. El problema con el duque de Híjar surgió por el mal uso que éste quiso hacer de una carta de la religiosa, respuesta a otra en la que él le había informado de la supuesta conspiración contra la Corona que se estaba preparando en mayo de 1648. La monja simplemente le aconsejó que se olvidara del tema o que, en todo caso, lo hablara con el rey. 
sión personal del rey, el epistolario abandona el tono político que había tenido hasta ese momento para volcarse en reflexiones y experiencias espirituales, reflejadas en recurrentes citas bíblicas. Según ha señalado Consolación Baranda, mientras que en las 30 cartas anteriores a 1647 tan sólo se advierten tres alusiones de esta naturaleza, luego comparecen en casi todas ${ }^{121}$.

Parafraseando a Juan de Arce de Otálora, con quien iniciábamos este trabajo, y sin desmerecer las demás ocupaciones conventuales, es evidente que sor María de Ágreda y Teresa de Jesús pasaron buena parte de sus vidas conventuales sentadas en sus escritorios, rodeadas de papeles, plumas y tintas. Diversas tablas barrocas las retratan en sus celdas con el brazo suspendido mientras reciben la inspiración divina o aplicadas a la tarea de escribir. Naturalmente, no fueron las únicas pero sí dos de las más representativas por la dimensión que adquirieron durante la Contrarreforma, la trascendencia posterior y la significación espiritual de sus escritos.

Distintos estudiosos se han ocupado de ellas con la finalidad de conocer mejor la magnitud de ambas monjas o de captar en sus obras diferentes ecos de las controversias religiosas y políticas que jalearon el tiempo que los tocó vivir, mientras que nuestro cometido se ha centrado en su faceta de escritoras de cartas en el contexto de la amplia difusión que la práctica epistolar alcanzó en los conventos femeninos barrocos. Tras sopesar distintos elementos de esta producción, indagando en las diferencias de estilo y en las culturas gráficas de las monjas, y desmenuzar las diversas funciones desempeñadas por las epístolas conventuales, he querido centrarme en una parte de la amplia correspondencia de dos religiosas tan relevantes como ellas con el propósito de reflexionar sobre los paradigmas epistolares que se apuntan en sus cartas. Siendo obvio que no todas sus misivas se ajustaron a la lectura preferente propuesta en estas páginas, en el epistolario de Teresa de Jesús y en la correspondencia de María de Jesús de Ágreda con el rey Felipe IV se aprecian dos modelos epistolares bien diferenciados. Mientras que las cartas de la monja de Ávila, si acaso con la excepción de las que escribió al padre Gracián, más imbuidas del tono característico de las epístolas espirituales, reflejan el valor cotidiano de la comunicación escrita en la reforma de las carmelitas descalzas y la mediación entre estas a través de la escritura; el epistolario de la religiosa concepcionista con el soberano se acomoda más al perfil de la "divina madre", es decir, a la autoridad moral desempeñada por aquellas religiosas a las que reyes y mandatarios acudieron en busca de consejo y sostén espiritual.

Así pues, la una aparece volcada en el destino de la orden que ella misma había fundado, en tanto que la otra se muestra más atenta a los requerimientos de un monarca atribulado por la crítica situación del reino en las décadas centrales del siglo XVI. Pero eso sí, pese a la singularidad y amplitud de sus epistolarios, no fueron ni mucho menos las únicas monjas que escribieron cartas, sino tal vez dos de las más destacadas epistológrafas del Barroco. Sus misivas y las de muchas otras religiosas, más las que

121 Baranda Leturio, C.: "La correspondencia de la M. Ágreda y su estilo literario", en La Madre Ágreda: una mujer del siglo XXI, op. cit. (nota 108), pp. 73-74. 
escribieron sus coetáneas laicas, desde las nobles hasta las emigrantes a América, dan fe de la capacidad femenina de subvertir los impedimentos que el discurso patriarcal aplicó en sus relaciones con lo escrito.

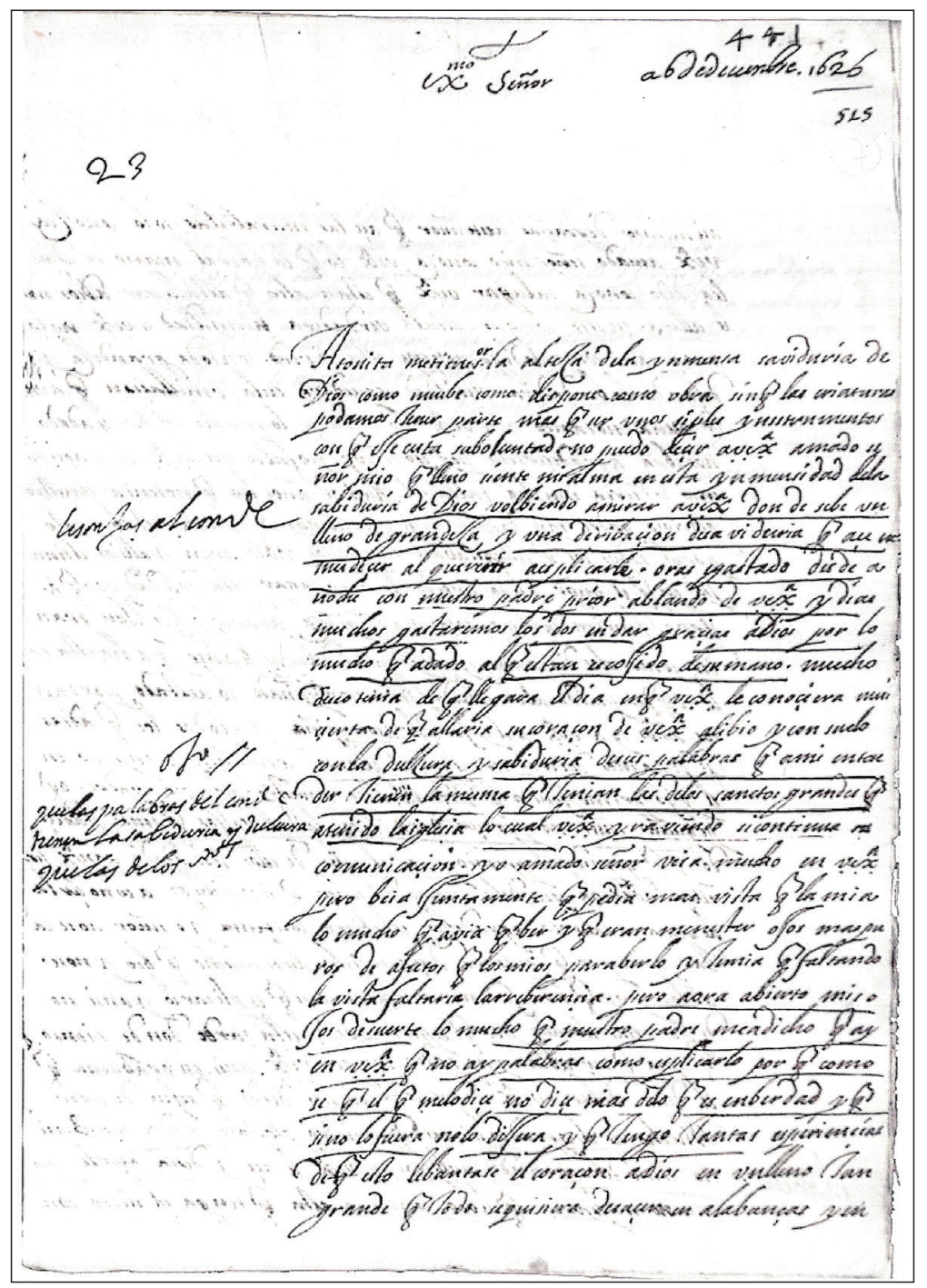

Fig. 1. Carta de Benedicta Teresa al conde-duque de Olivares (Madrid, Convento de la Encarnación, 6 de diciembre de 1626), AHN, Inquisición, leg. 3692 , fol. 515r. 


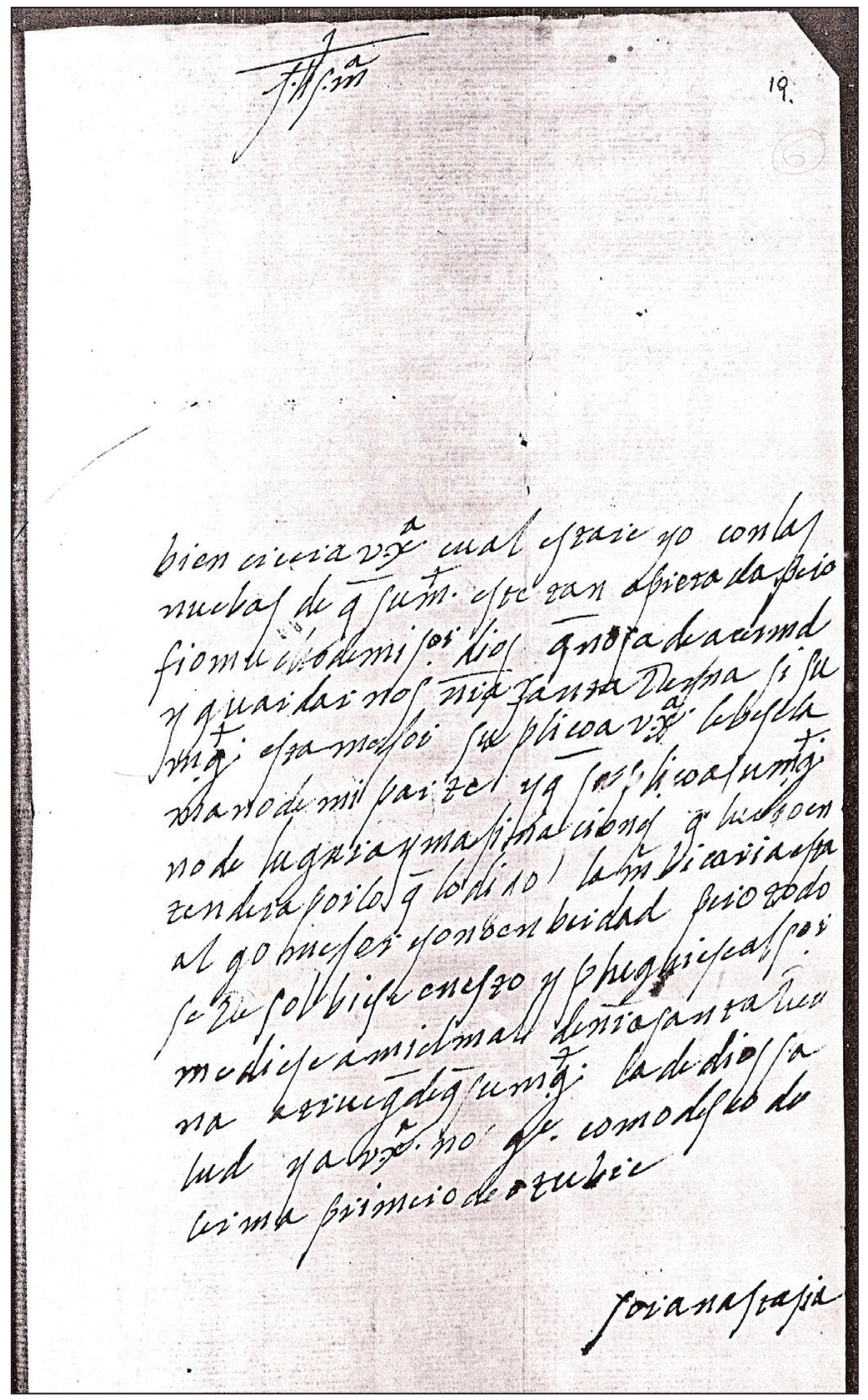

Fig. 2. Carta de Anastasia de la Encarnación pidiendo por la salud de la reina Margarita de Austria (Lerma, Monasterio de la Encarnación, 1 de octubre de [1611]), BNE, Ms. 12859, fol. 19r. 


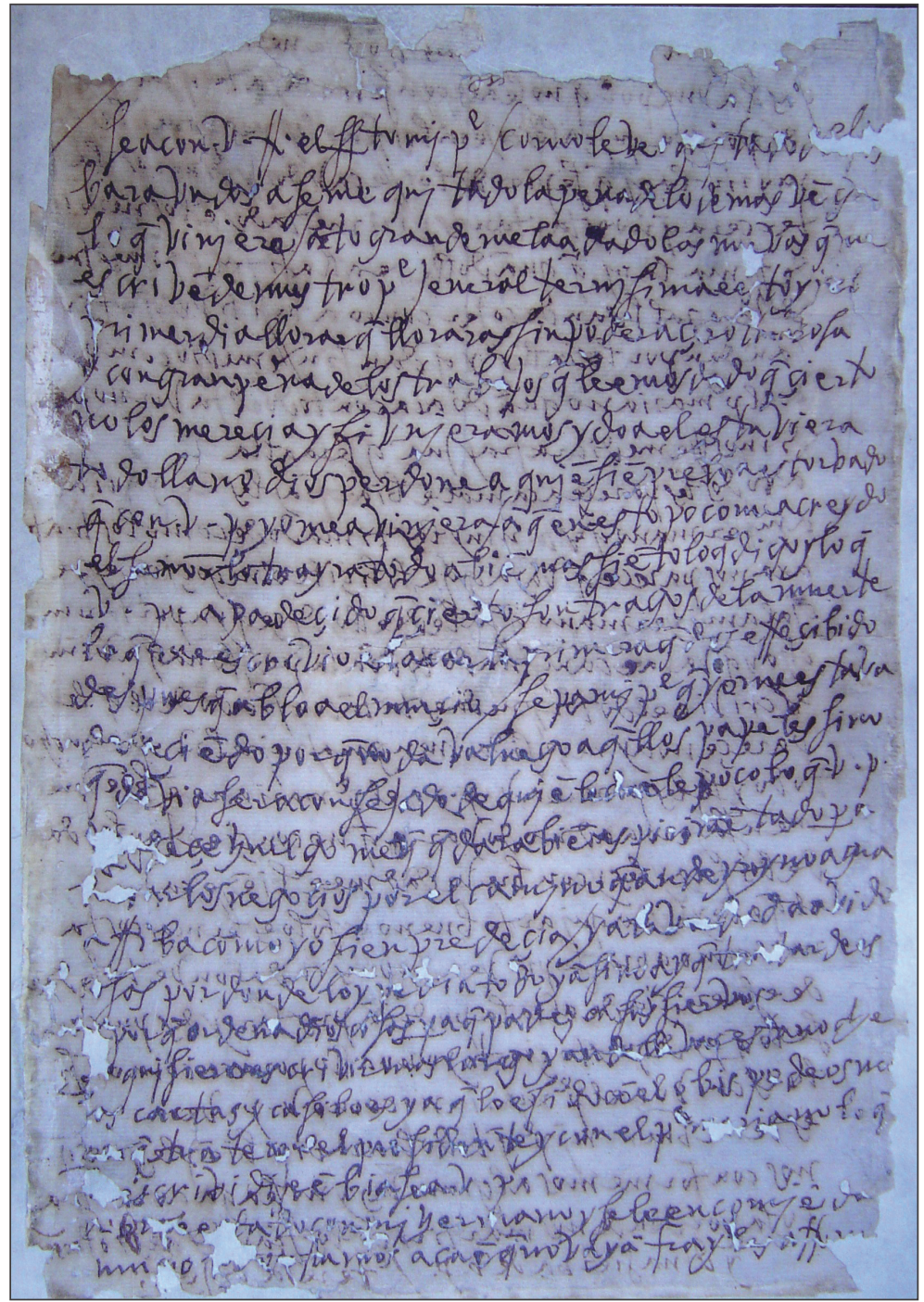

Fig. 3. Carta de Teresa de Jesús al padre Jerónimo Gracián (Malagón, 12 de diciembre de 1579), Alcalá de Henares, Convento de Carmelitas Descalzas del Corpus Christi, fol. 1r. 


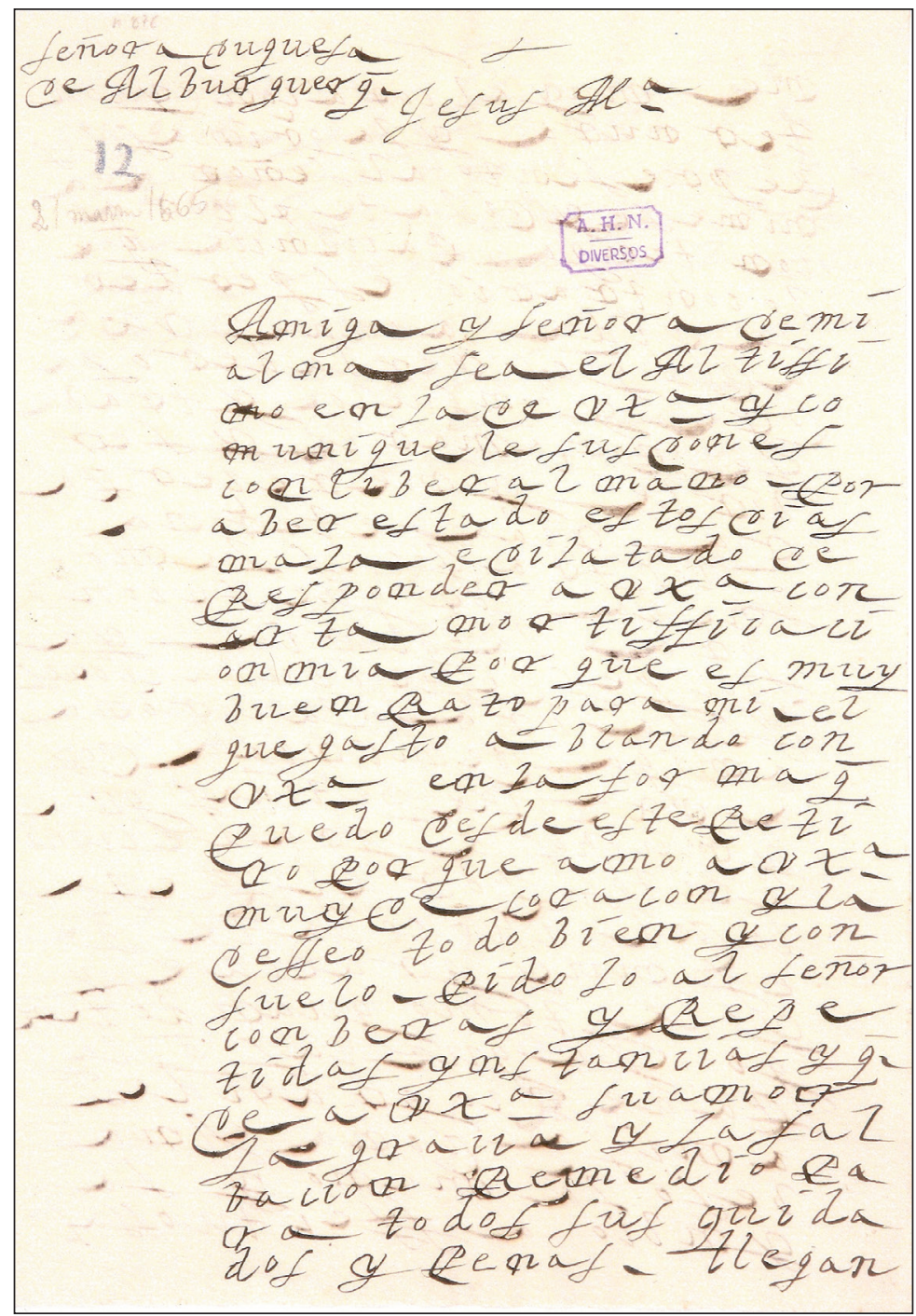

Fig. 4. Carta de sor María de Jesús Ágreda a la duquesa de Alburquerque (Ágreda, Monasterio de la Concepción, 21 de marzo de 1665), AHN, Diversos, Colecciones, 11, n. $876,33, n^{\circ} 12$, fol. $1 \mathrm{r}$. 